\title{
A Review on Individual and Combination Technologies of UV-C Radiation and Ultrasound in Postharvest Handling of Fruits and Vegetables
}

\author{
Okon Johnson Esua ${ }^{1,2}$, Nyuk Ling Chin ${ }^{1, * \mathbb{C}}$, Yus Aniza Yusof ${ }^{1}$ and Rashidah Sukor ${ }^{3}$ \\ 1 Department of Process and Food Engineering, Faculty of Engineering, Universiti Putra Malaysia, \\ UPM Serdang, Selangor 43400, Malaysia; johnsonesua@uniuyo.edu.ng (O.J.E.); \\ yus.aniza@upm.edu.my (Y.A.Y.) \\ 2 Department of Agricultural and Food Engineering, Faculty of Engineering, University of Uyo, \\ Uyo 520101, Akwa Ibom, Nigeria \\ 3 Department of Food Science, Faculty of Food Science and Technology, Universiti Putra Malaysia, \\ UPM Serdang, Selangor 43400, Malaysia; rashidah@upm.edu.my \\ * Correspondence: chinnl@upm.edu.my; Tel.: +60-39-7696353
}

Received: 24 September 2020; Accepted: 29 October 2020; Published: 10 November 2020

\begin{abstract}
Ultraviolet-C radiation and ultrasound technology are widely accepted and continuously being appraised as alternatives to conventional thermal techniques for decontamination of fruits and vegetables. However, studies in these areas have presented challenges related to quality, safety, limited capability, and cost of energy. This review paper presents an up-to-date summary of applications of ultraviolet- $C$ radiation and ultrasound technology for postharvest handling of fruits and vegetables from relevant literature. The limitations associated with applications of ultraviolet-C radiation and ultrasound technology individually has prompted their combination alongside other antimicrobial strategies for enhanced bactericidal effect. The combination of ultraviolet-C radiation and ultrasound technology as a hurdle approach also provides enhanced efficiency, cost effectiveness, and reduced processing time without compromising quality. The review includes further scope of industrial-led collaboration and commercialization of ultraviolet- $C$ radiation and ultrasound technology such as scale-up studies and process optimization.
\end{abstract}

Keywords: deterioration; cavitation; dosage; hurdle technology; microorganisms; nonthermal; decontamination

\section{Introduction}

Fruits and vegetables are an essential component of our diet and their consumption increases yearly due to perceived interest of consumers in healthy and functional foods [1,2]. However, they are susceptible to postharvest moisture loss, improper handling, mechanical damage, and microbial contamination. Postharvest moisture loss affects maturation, which can be inferred from evaluation of important quality parameters such as weight, texture, acidity, sugars, carotenoids, vitamins, and phenolic compounds. Microbial contamination is accompanied by postharvest losses and prevalence of foodborne disease outbreaks. Data suggest that about one-third of food (1.3 billion tons) fit for human consumption is wasted yearly, with $44 \%$ attributed to fruits and vegetables, while numerous foodborne illnesses and deaths linked to fresh produce contamination have been reported in the last two decades [3-6]. Food losses and wastes pose serious concern at a global level; hence, the United Nations agenda has initiatives with development investments towards preventing and reducing postharvest losses [6,7]. 
The common practices to reduce spoilage and enhance shelf life of fruits and vegetables include washing with sanitizers, refrigeration, controlled atmosphere storage using natural and synthetic preservative agents, and drying [8-14]. The majority of these approaches are marginally effective and may alter nutritional properties while the corrosive nature of some sanitizers has been linked with environmental and health concerns $[15,16]$. As consumer demands for minimally processed products with fresh-like characteristics has increased in recent times, this preoccupation has encouraged continuous evaluation of non-thermal technologies for postharvest handling of fruits and vegetables.

The non-thermal technologies of ultraviolet-C (UV-C) radiation and ultrasound (US) technology have been extensively studied for surface decontamination of fruits and vegetables, and are considered highly efficient, non-toxic, and environmentally friendly [17]. UV-C radiation is generated at wavelengths of 250-280 nm and is reported to disrupt functionality and integrity of microorganisms' DNA in addition to being linked with generation of reactive oxygen species that regulates physiological processes to induce secondary metabolite production [18]. On the other hand, US technology is a form of pressure waves beyond human hearing $(>20 \mathrm{kHz})$, and high intensity US at low frequencies of 20-100 kHz can induce acoustic cavitation that generates reactive hydroxyl radicals associated with microbial inactivation and stimulation of secondary metabolite accumulation in fruits and vegetables $[17,19,20]$.

Nevertheless, UV-C radiation can only penetrate up to several millimeters and US technology consumes high energy coupled with long treatment time, which limits their applications. This has encouraged the use of UV-C radiation and US technology in combination with other techniques for postharvest handling of fruits and vegetables with encouraging results $[1,19,21-23]$. The current review, drawn from selected past and current literature, presents research progress of the individual and combination approaches of UV-C radiation and US technologies in postharvest handling of fruits and vegetables. The types of disinfecting systems typically utilized for postharvest UV-C radiation and US technology decontamination of fruits and vegetables is also summarized. This review also included discussion on limitations associated with individual applications of UV-C radiation and US technology for postharvest decontamination of fruits and vegetables. The potential of a hurdle technology utilizing UV-C radiation and US technology in combination or simultaneously for maximizing and harnessing their advantages is also presented.

\section{Applications of UV-C Radiation in Postharvest Handling of Fruits and Vegetables}

\subsection{Disinfecting Systems and Factors Affecting Efficiency}

The use of UV-C radiation for food preservation was discovered in the 1930s, and the first studies on fruits and vegetables was recorded in 1977 when resveratrol and viniferins were induced in grape vine from UV-C exposure [24,25]. The efficacy of UV-C radiation for decontamination of fruits and vegetables is heavily dependent upon the type of disinfection systems, mode of applications, pulse intensity, morphology and location of microorganisms on fruits and vegetables, distance from irradiation source, and type of microorganism.

Typical systems for exposing fruits and vegetables to UV-C radiation consist of self-contained chambers with fluorescent germicidal lamps and have been widely reported in the literature. However, modifications to the conventional self-contained chambers have been reported to induce improved microbial reductions and maintain quality properties even at low UV-C radiation doses. For instance, Collazo et al. [23] showed that low doses of $0.1-0.3 \mathrm{~kJ} / \mathrm{m}^{2}$ from water-assisted UV-C radiation equipment with pressurized water sprinklers were enough to reduce respiration, maintain quality, and provoke 0.9-2.0 $\log$ CFU/g (log colony forming unit/g) reductions of Listeria monocytogenes (L. monocytogenes) and Salmonella enterica (S. enterica) in lettuce and spinach (Figure 1a). The study revealed that dual action of irradiation by immersion and simultaneous actions of process water from modification of the conventional treatment chambers with pressurized water sprinklers accounted for higher efficiency. Yan et al. [26] demonstrated that it is possible to reduce large variations and maximize UV-C radiation dose on fruit surfaces in disinfecting systems. In this study, conveyor belts were placed at 
a distance of $14 \mathrm{~cm}$ from UV-C lamps to convey and rotate fruits between two treatment chambers connected by an inclined belt (Figure $1 \mathrm{~b}$ ). This inclusion to the conventional UV-C lamp self-contained chambers ensured dose uniformity such that fruits received an average dose of $1 \mathrm{~kJ} / \mathrm{m}^{2}$, compared with $0.2 \mathrm{~kJ} / \mathrm{m}^{2}$ received by fruits without rotation. The modified rotation device ensured $1.3-1.8$ and 1.0-1.2 log CFU/fruit reductions in Escherichia coli O157:H7 (E. coli O157:H7) and E. coli ATCC 25922, respectively, compared with 0.5-0.7 log CFU/fruit reduction obtained without the rotation device, revealing the importance of dose uniformity for maximum effect of UV-C radiation in disinfection systems. Likewise, a benchtop UV-C radiation system that allowed upward and downward movement of fruits from a rotating roller was employed by Taze and Unluturk [27] to ensure uniformity of intensity (Figure 1c). They observed 3.0 and $2.38 \mathrm{log}$ CFU/g reductions in total aerobic mesophilic bacteria and yeast and mold, respectively, at doses of 31.01 and $7.75 \mathrm{~kJ} / \mathrm{m}^{2}$, and reported that light intensity was almost constant at the lamp center and lower at both ends. Ensuring the uniformity of exposure on food surfaces due to the low penetrative ability of UV-C radiation is seen as the most important challenge to commercialization, and these studies have provided an avenue to ensure dose uniformity for maximum impact.

The applied dosage of UV-C radiation, the type of microorganism, and their location on fruits and vegetables have been reported to have significant effect on decontamination efficiency of UV-C radiation. Mukhopadhyay et al. [28] showed that increasing UV-C radiation doses from 0.6 to $6.0 \mathrm{~kJ} / \mathrm{m}^{2}$ resulted in 2.2-3.1 and 2.3-3.5 log CFU/fruit reductions, respectively, for cocktail mixtures of $S$. enterica and E. coli O157:H7 on the surfaces of tomato. Lower reductions of 1.9-2.8 and 1.7-3.2 log CFU/fruit, respectively, were recorded on the stem scar under the same conditions, indicating that specific location of microorganisms on produce may influence efficacy of treatment and should be considered during the design of UV-C radiation disinfection systems. Further analysis showed that color and texture of tomato were not affected by the increasing dosages. In contrast, Lim and Harrison [29] observed a reduction range of 3.22-4.39 $\log$ CFU/g in S. enterica for a dosage range of $0.223-1.785 \mathrm{~kJ} / \mathrm{m}^{2}$, irrespective of the contamination location on tomato placed in a close end reflector lined with aluminum foil. The high reduction from such low doses was attributed to the bacterial strain and low initial inoculum level utilized in the study, which corroborates the assertion that the sensitivity of bacteria to UV-C radiation may vary among species and strains of the same species.

The mode of application of UV-C radiation, pulse intensity, and distance of samples from irradiation source have also been reported to influence the actions of $\mathrm{UV}-\mathrm{C}$ radiation during decontamination of fruits and vegetables. For example, short pulses of incident UV-C irradiance was not effective in reducing microbial population, which could be linked to ability of resistant strains of microorganism to produce protein protection mechanism against UV-C radiation treatment, especially at short treatment duration [30]. The study showed that there was no significant difference in log reductions (1.0 $\log$ CFU/g) of resistant strains of Enterococcus faecalis on zucchini squashes when a UV-C radiation system was operated in continuous incidence radiation of $0.011 \mathrm{~kJ} / \mathrm{m}^{2}$ or pulse irradiation of $0.067 \mathrm{~kJ} / \mathrm{m}^{2}$ in a discontinuous fluence. In addition, a continuous UV-C incidence radiation of $0.011 \mathrm{~kJ} / \mathrm{m}^{2}$ for $90 \mathrm{~s}$ did not have any significant effect on the reduction of Deinococcus radiodurans on zucchini squashes. However, higher inactivation of $E$. coli was reported on tomatoes and lettuce when the intensity of UV-C radiation was increased from 6.5 to $16 \mathrm{~W} / \mathrm{m}^{2}$ in a treatment cabinet [31]. Enhanced reductions of 2.8 and $1.7 \log$ CFU/g were also observed in tomatoes and lettuce, respectively, for samples closer to the radiation source at $31 \mathrm{~cm}$ compared with samples placed at a distance of $70 \mathrm{~cm}$. In the same vein, Cote et al. [32] observed that increasing intensity for a given dose could maximize the benefits of UV-C radiation. For an applied dosage of $4 \mathrm{~kJ} / \mathrm{m}^{2}$, only $5 \%$ of tomatoes irradiated with higher intensity of $33 \mathrm{~W} / \mathrm{m}^{2}$ showed incidences of postharvest rot caused by Botrytis, compared with $8 \%$ from lower intensity of $3 \mathrm{~W} / \mathrm{m}^{2}$, after 9 days of storage. On the other hand, $12 \%$ of strawberries irradiated with higher intensity showed decay symptoms after 5 days, compared with $46 \%$ of strawberries irradiated with lower intensity. The treatment also delayed ripening and maintained better quality of the fruits, while titratable acidity, soluble solids, and antioxidants properties were unaffected. 

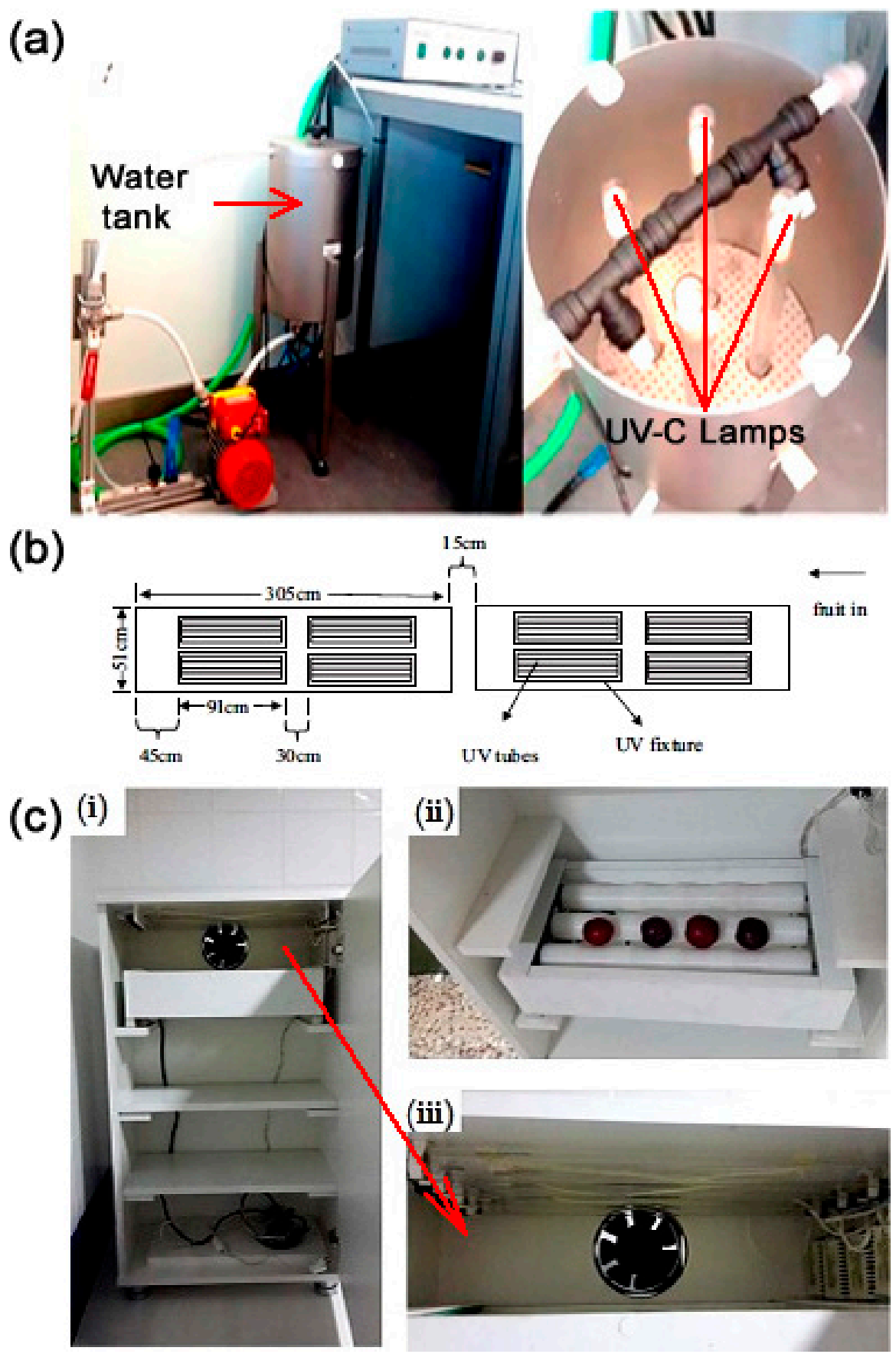

Figure 1. Disinfecting systems for UV-C radiation decontamination of fruits and vegetables. (a) Water-assisted UV-C set-up. Reproduced with permission from Collazo et al., International Journal of Food Microbiology; published by Elsevier, 2019. (b) Schematic diagram of a commercial UV-C treatment chamber. Reproduced with permission from Yan et al., Postharvest Biology and Technology; published by Elsevier, 2014. (c) Benchtop UV-C set-up with (i) tray system, (ii) rotating roller bearing, and (iii) UV-C lamps and cooling system. Reproduced with permission from Taze and Unluturk, Scientia Horticulturae; published by Elsevier, 2018.

The influence of fruit surface characteristics on the inactivation efficiency of UV-C radiation has also been studied, with results demonstrating that microorganisms on fruits' surfaces responded differently to UV-C radiation [33]. It was observed that microbial inactivation was lower for fruits with rougher surfaces (strawberry, cantaloupe, and raspberry) compared to less hydrophobic fruits with smoother surfaces (pear and apple). Reductions of 2.9 and $2.1 \log$ CFU/g were recorded for 
E. coli $\mathrm{O} 157: \mathrm{H7}$ on apple and pear surfaces, respectively, at $0.9 \mathrm{~kJ} / \mathrm{m}^{2}$ for $60 \mathrm{~s}$ compared with 2.0 and $1.1 \log$ CFU/g recorded for strawberry and raspberry at 7.2 and $10.5 \mathrm{~kJ} / \mathrm{m}^{2}$ for 480 and $720 \mathrm{~s}$, respectively. On the other hand, L. monocytogenes showed more resistance than E. coli O157:H7, revealing 1.6 and $1.7 \log$ CFU/g reductions, respectively, on apple and pear at $3.75 \mathrm{~kJ} / \mathrm{m}^{2}$ and $11.9 \mathrm{~kJ} / \mathrm{m}^{2}$. The log reduction of L. monocytogenes was $1.0 \log C F U / g$ on both cantaloupe and strawberry at $11.9 \mathrm{~kJ} / \mathrm{m}^{2}$. The findings from this study were corroborated by Syamaladevi et al. [34] by using a similar device when they observed that trichomes on peach surfaces and wounds on pears protected and shielded microorganisms from irradiation, while smaller surface roughness and spreading coefficient of pear surfaces compared with peach likely caused a more uniform distribution of microbial cells on pear surfaces. Maximum reductions of $3.70 \log \mathrm{CFU} / \mathrm{g}$ were recorded for E. coli on intact pear surfaces, with lower reductions of 3.10 and $2.91 \log \mathrm{CFU} / \mathrm{g}$ achieved on wounded pear and peach surfaces, respectively, after $4 \mathrm{~min}$ at $7.56 \mathrm{~kJ} / \mathrm{m}^{2}$.

\subsection{Effects of UV-C Radiation on Microorganism Inactivation and Quality of Fruits and Vegetables}

Table 1 lists studies that have used UV-C radiation to inactivate microorganisms and subsequent effects on quality parameters for a wide variety of fruits and vegetables. Collectively, these studies demonstrate the potential of UV-C radiation at low doses of $0.00176-1 \mathrm{~kJ} / \mathrm{m}^{2}$ for enhancing bioactive compound production, reducing enzymatic activities, extending shelf life, and having degradative effects on biological process-regulating proteins responsible for deteriorative changes of postharvest produce [33,35-39]. The range of doses were also responsible for 1.2-2.9 $\log$ CFU/g reduction in E. coli O157:H7, Salmonella spp., and Listeria spp., as well as reduced rot and decay development. In contrast, Wang et al. [40] observed that a low dose of $0.3 \mathrm{~kJ} / \mathrm{m}^{2}$ had no effect on total bacteria number and browning-related enzymes of fresh cut lotus during storage, and resulted in a high degree of browning, but the authors maintained that a moderate dose of $1.5-3 \mathrm{~kJ} / \mathrm{m}^{2}$ significantly retarded microbial growth and suppressed the activities of browning-related enzymes. Pinheiro et al. [41] also reported that low doses of $0.97 \mathrm{~kJ} / \mathrm{m}^{2}$ was not adequate for metabolic degradation delay in tomatoes but presented $2.1 \log$ CFU/g reduction in mesophilic load, delayed red color development, and caused increases in firmness and phenolic content. The variations in results could be attributed to the factors discussed earlier, in addition to the type of disinfection systems used.

It is apparent that increasing dosage applications could result in increased microbial reduction. For instance, Sommers et al. [42] observed a progressive increase from 2.59 to $3.79 \mathrm{log} \mathrm{CFU} / \mathrm{g}$ in the inactivation of L. monocytogenes, Salmonella spp., and Staphylococcus aureus (S. aureus) on Roma tomatoes and jalapeño peppers when the dosage was increased from 5 to $40 \mathrm{~kJ} / \mathrm{m}^{2}$. Similarly, successive increases in UV-C radiation doses evoked greater reductions of E. coli, S. aureus, S. Enteritidis, and Listeria innocua (L. innocua) on tomato, lettuce, and strawberry, with no modifications in texture and appearance $[19,43]$. Doubling UV-C radiation dose from 32 to $72 \mathrm{~kJ} / \mathrm{m}^{2}$ also doubled the reduction of human adenoviruses from 0.92 to 2.22 and 1.26 to 3.98 logs for tomato and strawberry, respectively. 
Table 1. List of fruits and vegetables treated with UV-C radiation

\begin{tabular}{|c|c|c|c|c|}
\hline \multirow{2}{*}{$\begin{array}{c}\text { Fruit/ } \\
\text { Vegetable }\end{array}$} & \multirow{2}{*}{ UV-C Parameters } & \multicolumn{2}{|c|}{ Main Findings } & \multirow{2}{*}{ Sources } \\
\hline & & Quality Improvement Attributes & Microbial Log Reduction and Disease Incidence & \\
\hline \multirow{3}{*}{ Apple } & $7.5 \mathrm{~kJ} / \mathrm{m}^{2}+$ blanching & \multirow{3}{*}{$\begin{array}{c}\text { Retained color } \\
\text { Retained color and physicochemical } \\
\text { properties }\end{array}$} & L. innocua, E. coli, Saccharomyces cerevisiae: 1-1.19 & {$[44]$} \\
\hline & $1.0 \mathrm{~kJ} / \mathrm{m}^{2}$ & & E. coli: 1.89, L. innocua, S. enterica: 1.5 & \\
\hline & $0.92-5 \mathrm{~kJ} / \mathrm{m}^{2}, 60-300 \mathrm{~s}$ & & E. coli: 2.9, L. monocytogenes: 1.6 & {$[33]$} \\
\hline \multirow{3}{*}{ Apricot } & $0.74 \mathrm{~kJ} / \mathrm{m}^{2}, 10 \mathrm{~s}$ & - & E. coli: 1.2, Salmonella spp.: 1.5 & [37] \\
\hline & $1.0-2.54 \mathrm{~kJ} / \mathrm{m}^{2}$ & - & E. coli O157:H7: 0.5-1.8 & [26] \\
\hline & $7.75 \mathrm{~kJ} / \mathrm{m}^{2}$ & - & Yeast and mold: 2.38 , TAPC: 3.0 & [27] \\
\hline \multirow[b]{2}{*}{ Blueberry } & $2 \mathrm{~kJ} / \mathrm{m}^{2}, 600 \mathrm{~s}$ & \multirow{2}{*}{$\begin{array}{l}\text { Increased anthocyanin, phenols, and } \\
\text { antioxidants }\end{array}$} & Colletotrichum acutatum: $10 \%$ reduction & [45] \\
\hline & $\begin{array}{l}9.54 \mathrm{~kJ} / \mathrm{km}^{2}, 120 \mathrm{~s},+ \\
\mathrm{O}_{3}, 60 \mathrm{~s}\end{array}$ & & E. coli: $3.08-3.8$ & {$[46]$} \\
\hline Broccoli & $\begin{array}{c}2.5-7.5 \mathrm{~kJ} / \mathrm{m}^{2},+100 \\
\mathrm{mg} / \mathrm{L} \mathrm{NEW}+\mathrm{MAP}+ \\
\mathrm{PA}\end{array}$ & $\begin{array}{l}\text { Retained total phenols and antioxidants; } \\
\text { increased enzyme activity, reduced steric } \\
\text { and } \alpha \text {-linolenic acid }\end{array}$ & $\begin{array}{l}\text { L. monocytogenes: } 0.72, \text { E. coli, } S \text {. Enteritidis: } \\
\text { 1.22-3.0, psychrophilic bacteria: } 1.3\end{array}$ & {$[11,47]$} \\
\hline \multirow[t]{2}{*}{ Carrot } & $0.78 \mathrm{~kJ} / \mathrm{m}^{2}$ & $\begin{array}{c}\text { Increased bioactive compounds and } \\
\text { whiteness index; reduced enzyme activity } \\
\text { and } \mathrm{O}_{2} / \mathrm{CO}_{2} \text { rate }\end{array}$ & Aerobic mesophile: 1.7 & [36] \\
\hline & $57.6 \mathrm{~kJ} / \mathrm{m}^{2}, 3600 \mathrm{~s}$ & $\begin{array}{l}\text { Increased enzyme reaction and whiteness } \\
\text { index }\end{array}$ & - & [31] \\
\hline Cauliflower & $5 \mathrm{~kJ} / \mathrm{m}^{2}, 30 \mathrm{~s}+\mathrm{AMF}$ & & $\begin{array}{l}\text { L. monocytogenes: } 1.5, \text { E. coli: } 2.0 \text {, yeast and mold: } \\
2.0\end{array}$ & [13] \\
\hline Date palm & $6.22 \mathrm{~kJ} / \mathrm{m}^{2},+\mathrm{O}_{3}$ & $\begin{array}{c}\text { Increased antioxidants and TA; reduced } \\
\text { sugar and water activity }\end{array}$ & 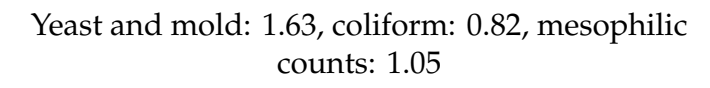 & {$[48]$} \\
\hline Grape & $\begin{array}{l}6 \mathrm{~kJ} / \mathrm{m}^{2},+0.5 \% \\
\text { chitosan }\end{array}$ & $\begin{array}{l}\text { Increased resveratrol, reduced } \\
\text { respiration, weight loss }\end{array}$ & Botrytis cinerea: growth inhibition & [49] \\
\hline \multirow{3}{*}{ Lettuce } & $57.6 \mathrm{~kJ} / \mathrm{m}^{2}, 3600 \mathrm{~s}$ & Overall quality parameters maintained & E. coli: 1.7 & {$[31]$} \\
\hline & $\begin{array}{l}24-72 \mathrm{~kJ} / \mathrm{m}^{2} \\
1200-3600 \mathrm{~s}\end{array}$ & & $\begin{array}{c}\text { E coli: } 1.75, \text { L. innocua: } 1.27, \text { S. aureus: } 1.21, \text { S. } \\
\text { Enteritidis: } 1.39, \text { HAdV: } 2.13\end{array}$ & {$[19,43]$} \\
\hline & $\begin{array}{c}0.1-0.5 \mathrm{~kJ} / \mathrm{m}^{2}, 60-300 \mathrm{~s} \\
\text { PA + MAP }\end{array}$ & $\begin{array}{l}\text { Oxidative discoloration, enhanced } \\
\text { respiration }\end{array}$ & 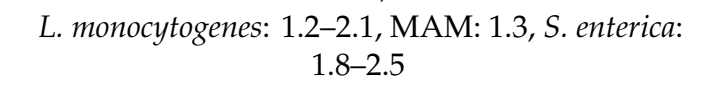 & [23] \\
\hline
\end{tabular}


Table 1. Cont

\begin{tabular}{|c|c|c|c|c|}
\hline \multirow{2}{*}{$\begin{array}{c}\text { Fruit/ } \\
\text { Vegetable }\end{array}$} & \multirow{2}{*}{ UV-C Parameters } & \multicolumn{2}{|c|}{ Main Findings } & \multirow{2}{*}{ Sources } \\
\hline & & Quality Improvement Attributes & Microbial Log Reduction and Disease Incidence & \\
\hline $\begin{array}{l}\text { Lotus root } \\
\text { (fresh cut) }\end{array}$ & $0.3-12 \mathrm{~kJ} / \mathrm{m}^{2}, 60-2400 \mathrm{~s}$ & $\begin{array}{l}\text { Low browning degree and soluble } \\
\text { quinone content; inactivation of PAL, } \\
\text { POD, TSS; hardness maintained }\end{array}$ & Total bacteria: $1.0-1.4$ & [40] \\
\hline \multirow[t]{2}{*}{ Mango } & $\begin{array}{c}0.00176-0.00706 \mathrm{~kJ} / \mathrm{m}^{2} \\
900-1800 \mathrm{~s}\end{array}$ & $\begin{array}{c}\text { Increased flavonoid and antioxidant } \\
\text { activity }\end{array}$ & Microbial load under acceptable limit & {$[39]$} \\
\hline & $5 \mathrm{~kJ} / \mathrm{m}^{2}$ & - & E. coli: 1.98, Cronobacter sakazakii: 2.60 & {$[50]$} \\
\hline \multirow{3}{*}{ Melons } & $11.9 \mathrm{~kJ} / \mathrm{m}^{2}, 840 \mathrm{~s}$ & - & L. monocytogenes: 1.0 & [33] \\
\hline & $1.2 \mathrm{~kJ} / \mathrm{m}^{2}, 60 \mathrm{~s}$ & Retained physicochemical properties & TVC: 2.16 , Enterobacteriaceae: 2.62 & [51] \\
\hline & $2.8 \mathrm{~kJ} / \mathrm{m}^{2}$ & Color, lycopene, vitamin C preserved & Enterobacteria, AMB, APB: 2.0 & {$[52]$} \\
\hline Peach & $4 \mathrm{kJm}^{2}, 120 \mathrm{~s}$ & & E. coli: 2.5 & [34] \\
\hline \multirow{4}{*}{ Pear } & $1.7-4 \mathrm{~kJ} / \mathrm{m}^{2}, 90-180 \mathrm{~s}$ & Maintained weight, TSS, and texture & Penicillium expansum: $2.7-2.8$, E. coli: $2.6-3.59$ & {$[34,53]$} \\
\hline & $\begin{array}{c}0.92-11.9 \mathrm{~kJ} / \mathrm{m}^{2} \\
60-840 \mathrm{~s}\end{array}$ & - & E. coli: 2.1, L. monocytogenes: 1.7 & {$[33]$} \\
\hline & $87 \mathrm{~kJ} / \mathrm{m}^{2}, 1200 \mathrm{~s}$ & - & L. monocytogenes, E. coli: 2.6-3.4 & [54] \\
\hline & $7.5 \mathrm{kJm}^{2}$ & $\begin{array}{l}\text { Increased firmness; color, TA, and TSS } \\
\text { maintained }\end{array}$ & E. coli: 3.2, L. innocua: 2.9 , S. enterica: 2.8 & {$[55]$} \\
\hline \multirow{2}{*}{ Pepper } & $5-40 \mathrm{~kJ} / \mathrm{m}^{2}$ & - & S. aureus: $3.09-3.73$, L. monocytogenes: $3.11-3.72$ & [42] \\
\hline & $1.483 \mathrm{~kJ} / \mathrm{m}^{2}, 120 \mathrm{~s}$ & Improved firmness; color preserved & L. innocua: 1.05 & [56] \\
\hline Pineapple & $\begin{array}{l}0.2-4.8 \mathrm{~kJ} / \mathrm{m}^{2}+\mathrm{PET} \\
\text { pouches }\end{array}$ & Maintained quality and color & $\begin{array}{l}\text { LAB, yeast and mold: } 0.20-2.0, \text { Enterobacteriaceae: } \\
\text { undetected }\end{array}$ & [57] \\
\hline Plum & $\begin{array}{l}10 \mathrm{~kJ} / \mathrm{m}^{2}+\mathrm{ClO}_{2}+ \\
\text { fumaric acid }\end{array}$ & - & E. coli: $2.07-5.48$, L. monocytogenes: $1.62-6.26$ & [58] \\
\hline Pomegranate & $1.13 \mathrm{~kJ} / \mathrm{m}^{2},+\mathrm{MAP}$ & $\begin{array}{l}\text { Anthocyanin; antioxidant activity } \\
\text { maintained }\end{array}$ & $\mathrm{LAB}, \mathrm{AMB}$, Enterobacteriaceae: reduced growth & [59] \\
\hline Raspberry & $7.2 \mathrm{~kJ} / \mathrm{m}^{2}, 480 \mathrm{~s}$ & - & E. coli: 1.0 & [33] \\
\hline \multirow{3}{*}{ Spinach } & $4.54 \mathrm{~kJ} / \mathrm{m}^{2}$ & $\begin{array}{l}\text { Chlorophyll maintained; low ethylene } \\
\text { production }\end{array}$ & $\begin{array}{c}\text { Mesophilic, psychrophilic, coliform, } \\
\text { enterobacteria: } 1.1\end{array}$ & [60] \\
\hline & $\begin{array}{c}0.212-0.848 \mathrm{~kJ} / \mathrm{m}^{2} \\
\mathrm{ClO}_{2}\end{array}$ & Color and texture maintained & $\begin{array}{l}\text { E. coli: } 2.01-5.17 \text {, Salmonella Typhimurium: } \\
2.10-5.47, \text { L. monocytogenes: } 1.70-4.32\end{array}$ & [16] \\
\hline & $\begin{array}{c}0.1-0.5 \mathrm{~kJ} / \mathrm{m}^{2}, 60-300 \mathrm{~s} \\
\mathrm{PA}+\mathrm{MAP}\end{array}$ & Reduced respiration; maintained quality & $\begin{array}{l}\text { L. monocytogenes: } 0.5-2.2, \text { MAM: } 1.3 \text {, S. enterica: } \\
\qquad 0.8-2.0\end{array}$ & [23] \\
\hline
\end{tabular}


Table 1. Cont.

\begin{tabular}{|c|c|c|c|c|}
\hline \multirow{2}{*}{$\begin{array}{c}\text { Fruit/ } \\
\text { Vegetable }\end{array}$} & \multirow{2}{*}{ UV-C Parameters } & \multicolumn{2}{|c|}{ Main Findings } & \multirow{2}{*}{ Sources } \\
\hline & & Quality Improvement Attributes & Microbial Log Reduction and Disease Incidence & \\
\hline \multirow{5}{*}{ Strawberry } & $0.5 \mathrm{~kJ} / \mathrm{m}^{2}$ & Increased PAL and ethylene production & $\begin{array}{l}\text { B. cinera, Rhizopus stolonifier, Mucor sp.: reduced } \\
\text { incidence }\end{array}$ & [35] \\
\hline & $\begin{array}{l}0.92-11.9 \mathrm{~kJ} / \mathrm{m}^{2} \\
\quad 60-840 \mathrm{~s}\end{array}$ & - & E. coli: 2.0, L. monocytogenes: 1.0 & [33] \\
\hline & $\begin{array}{l}24-72 \mathrm{~kJ} / \mathrm{m}^{2} \\
1200-3600 \mathrm{~s}\end{array}$ & - & $\begin{array}{c}\text { E coli, S. aureus, S. Enteritidis, L. innocua: } 1-1.4, \\
\text { HAdV: } 2.85-3.98\end{array}$ & {$[19,43]$} \\
\hline & $3,33 \mathrm{~W} / \mathrm{m}^{2}, 4 \mathrm{~kJ} / \mathrm{m}^{2}$ & $\begin{array}{l}\text { Low weight loss and respiration rate; } \\
\text { increased anthocyanin }\end{array}$ & Botrytis cinera: reduced incidence & [32] \\
\hline & $1.483 \mathrm{~kJ} / \mathrm{m}^{2}, 120 \mathrm{~s}$ & Improved firmness; anthocyanin retained & Total mesophiles: 0.26 & [56] \\
\hline \multirow{9}{*}{ Tomato } & $5-40 \mathrm{~kJ} / \mathrm{m}^{2}$ & 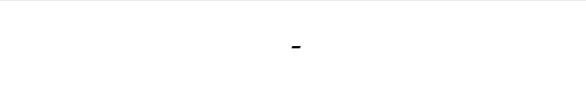 & $\begin{array}{c}\text { S. aureus: } 3.13-3.63, \text { Salmonella spp.: } 3.02-3.79, L . \\
\text { monocytogenes: } 2.59-3.60\end{array}$ & [42] \\
\hline & $0.97 \mathrm{~kJ} / \mathrm{m}^{2}, 180 \mathrm{~s}$ & $\begin{array}{l}\text { Low weight loss; improved firmness and } \\
\text { phenolic content }\end{array}$ & Total microbial count: $0.6-2.1$ & {$[41]$} \\
\hline & $0.6-6.0 \mathrm{~kJ} / \mathrm{m}^{2}, 10-100 \mathrm{~s}$ & Firmness and color maintained & E. coli: $2.3-3.5$, S. enterica: $2.2-3.1$ & [28] \\
\hline & $57.6 \mathrm{~kJ} / \mathrm{m}^{2}, 3600 \mathrm{~s}$ & Increase in tomato color index & E. coli: 2.8 & [31] \\
\hline & $2 \mathrm{~kJ} / \mathrm{m}^{2}, 500 \mathrm{~s}+\mathrm{MAP}$ & Increased lycopene; color maintained & S. Typhimurium: 1.3 & {$[61]$} \\
\hline & $\begin{array}{c}3,33 \mathrm{~W} / \mathrm{m}^{2}, 4 \mathrm{~kJ} / \mathrm{m}^{2} \\
120 \mathrm{~s}\end{array}$ & $\begin{array}{l}\text { Low weight loss and respiration rate; } \\
\text { bioactive and physicochemical content } \\
\text { retained }\end{array}$ & B. cinerea: reduced incidence & [32] \\
\hline & $3 \mathrm{~kJ} / \mathrm{m}^{2}$ & $\begin{array}{l}\text { Higher total phenol and firmness; } \\
\text { reduced ethylene production and } \\
\text { enzyme activity }\end{array}$ & Decrease in decay severity & [62] \\
\hline & $0.223-1.785 \mathrm{~kJ} / \mathrm{m}^{2}$ & Color and texture maintained & S. enterica: $3.22-4.39$ & [29] \\
\hline & $0.848 \mathrm{~kJ} / \mathrm{m}^{2},+\mathrm{ClO}_{2}$ & $\cos$ & $\begin{array}{l}\text { E. coli: } 2.27, \text { S. Typhimurium: } 2.20, \text { L. monocytogens: } \\
1.66\end{array}$ & [16] \\
\hline Watercress & $1.483 \mathrm{~kJ} / \mathrm{m}^{2}, 120 \mathrm{~s}$ & Improved firmness; color maintained & Total coliforms: 0.53 & [56] \\
\hline
\end{tabular}

TAPC: total aerobic plate count, NEW: neutral electrolyzed water, MAP: modified atmosphere packaging, PA: peroxyacetic acid, AMF: antimicrobial formulations, TA: titratable acidity, HAdV: human adenovirus, MAM: mesophilic aerobic microbes, PAL: phenylalanine, POD: peroxidase, TSS: total soluble solids, LAB: lactic acid bacteria, AMB: aerobic mesophilic bacteria, APB: aerobic psychrotrophic bacteria. 
The synergistic or additive effects of combining UV-C radiation with other techniques for improved efficiency have also been studied. Enhanced reductions of $3 \log \mathrm{CFU} / \mathrm{g}$ were recorded in the populations of E. coli and S. Enteritidis when UV-C radiation was combined with either neutral electrolyzed water or peroxyacetic acid for broccoli decontamination, compared with 1.3-2.2 log CFU/g obtained for individual application of UV-C radiation at $7.5 \mathrm{~kJ} / \mathrm{m}^{2}$ [11,47]. Combination treatment also maintained quality, retained bioactive and fatty acid contents, and was seen as a potential eco-friendly alternative to conventional $\mathrm{NaClO}$ application. Similar enhanced reductions in $E$. coli on blueberry, and L. monocytogenes, E. coli, and yeast and mold on cauliflower were also reported when low UV-C doses were combined with ozone and antimicrobial formulations [13,46]. The effects of combining UV-C radiation and $\mathrm{ClO}_{2}$ gas was also observed to be significantly greater than the sum of individual inactivation for the decontamination of spinach and tomato [16]. Individual UV-C radiation application at $0.848 \mathrm{~kJ} / \mathrm{m}^{2}$ reduced E. coli O157:H7 and Salmonella Typhimurium by 1.85 and $2.02 \log \mathrm{CFU} / \mathrm{g}$, respectively, while combined treatment reduced the population by 5.17 and $5.41 \log$ CFU/g on spinach and 5.62 and $5.46 \log$ CFU/g on tomato. Enhanced microbial reduction was attributed to cell membrane damage and changes to membrane permeability as a result of the synergistic actions of UV-C radiation and $\mathrm{ClO}_{2}$ gas. This position was also maintained by Kim and Song [58] during the sequential application of $\mathrm{ClO}_{2}$ gas and UV-C radiation on plum. The synergistic effect produced 4 and $3.27 \log$ CFU/g reductions in L. monocytogenes and E. coli O157:H7, respectively, compared with 1.62 and $2.07 \log \mathrm{CFU} / \mathrm{g}$ reductions obtained for individual UV-C radiation application. The authors however upheld that sequential applications of $\mathrm{ClO}_{2}$ gas, UV-C radiation, and fumaric acid, which produced 5.48 and $6.26 \log \mathrm{CFU} / \mathrm{g}$ reductions, respectively, in E. coli O157:H7 and L. monocytogenes, was the most effective combination treatment.

\section{Applications of US Technology in Postharvest Handling of Fruits and Vegetables}

\subsection{Disinfecting Systems and Factors Affecting Efficiency}

The antimicrobial effect of US technology was first documented 80 years ago, but its prospective practical application for microbial inactivation began in the 1960s [63]. The chemical reactivity of a system is affected by US technology through actions of cavitation and sonolysis from mechanical vibrations, typically produced from transformation of high-frequency electrical energy by piezoelectric transducers in probe or tank systems $[15,19]$. The threshold of cavitation bubble in the tank or probe systems is usually influenced by US frequency, power, intensity, and exposure time. The sonochemist typically uses frequencies of $20-50 \mathrm{kHz}$, as it is easier to obtain cavitation at these frequencies [64]. Together with the type of microorganism, mode of application in terms of pulse or continuous modes, and dual-mode or mono-mode frequency, these factors affect the efficiency of US technology during decontamination of fruits and vegetables.

For the US probe systems, a pulse mode application of $10 \mathrm{~s}$ on and $5 \mathrm{~s}$ off from a $15 \mathrm{~mm}$ diameter, $20 \mathrm{kHz}, 400 \mathrm{~W}$, and $226 \mathrm{~W} / \mathrm{cm}^{2}$ probe system submerged in water (Figure 2a) was capable of reducing initial total number of colonies and yeast and mold on cucumber by $0.49-1.02$ and $0.41-0.84 \log \mathrm{CFU} / \mathrm{g}$, respectively, with increasing treatment time from 5 to 15 min under modified atmosphere packaging storage [65]. Treatment up to 10 min effectively reduced losses of firmness, ascorbic acid, color, soluble solids, and weight, and maintained cell wall integrity. Further increase in treatment time led to deterioration of quality properties. Similarly, Millan-Sango et al. [66] reported $2.56 \log \mathrm{CFU} / \mathrm{cm}^{2}$ reduction in E. coli O157:H7 on lettuce leaves at pulse mode application of $10 \mathrm{~s}$ on and $6 \mathrm{~s}$ off from a $14 \mathrm{~mm}$ probe, $26 \mathrm{kHz}, 90 \mu \mathrm{m}$, and $200 \mathrm{~W}$ US system operating in both continuous and pulsed mode configurations. Results showed no significant differences between continuous and pulsed mode applications for up to $25 \mathrm{~min}$ of application, suggesting that decontamination efficacy was dependent upon treatment time rather than the configuration of the probe system utilized. 
(a)

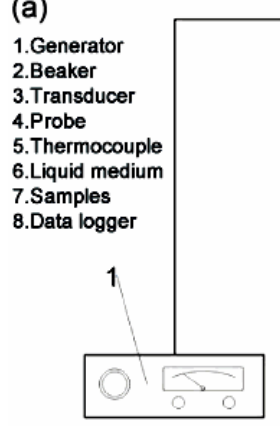

(b)

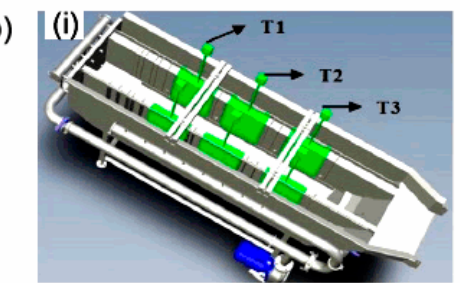

(c)
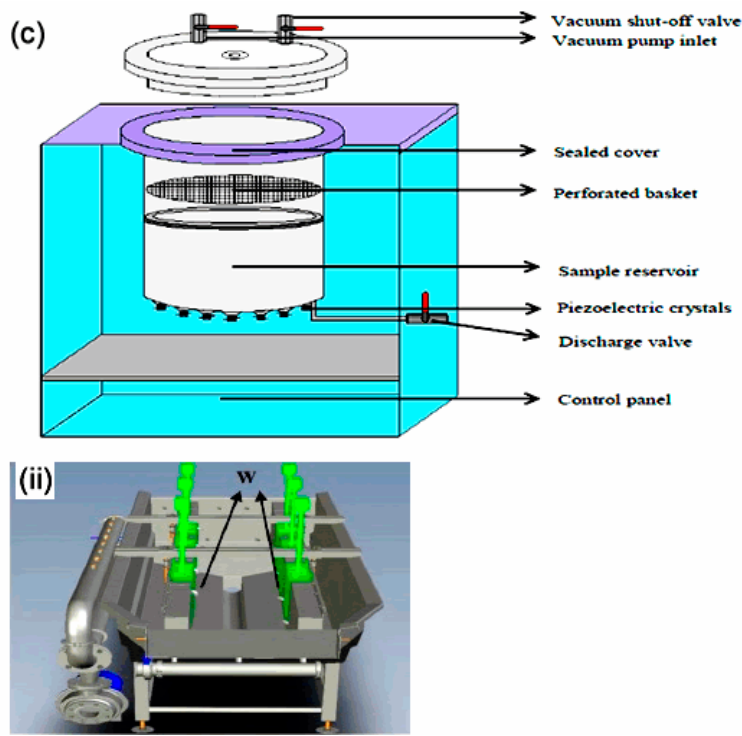

Figure 2. Typical disinfecting systems for ultrasound (US) technology decontamination of fruits and vegetables. (a) Schematic representation of US probe system. Reproduced with permission from Fan et al., Ultrasonics Sonochemistry; published by Elsevier, 2019. (b) Schematic diagram of US vacuum impregnation system. Reproduced with permission from Yilmaz and Bilek, Ultrasonics Sonochemistry; published by Elsevier, 2018. (c) Continuous-flow US bath equipment depicting (i) different transducers T1, T2, and T3, and (ii) washing area, W. Reproduced with permission from Zhou et al., Innovative Food Science and Emerging Technologies; published by Elsevier, 2012.

Increasing US intensity in a probe system has also been reportedly associated with enhanced antimicrobial activities while higher intensities had negative effects on product quality during storage. For example, reduced decay incidence of gray mold on strawberry with increasing intensity from 10.6-31.8 W/cm² was reported by Aday et al. [67] from a $1.9 \mathrm{~cm}$ diameter probe system operating at $20 \mathrm{kHz}$. Results also show that $\mathrm{pH}$, color, soluble solids, and sugar content of strawberry treated with 10.6-21.2 W/cm ${ }^{2}$ were better when compared with those treated with $31.8 \mathrm{~W} / \mathrm{cm}^{2}$, indicating that higher US intensity was detrimental to the quality of strawberry. In the same vein, Wang et al. [68] showed that the population of total bacteria and yeast and mold on tomato reduced to a range of 0.42-1.04 and 0.41-0.93 log CFU/g, respectively, with increasing US intensity from 66.64 to $145.74 \mathrm{~W} / \mathrm{L}$. Likewise, lower intensity levels inhibited ethylene production and respiration rates, and maintained firmness and antioxidant properties, while higher intensity had negative effects on tomato quality, demonstrating that appropriate US intensity can inhibit decay and maintain nutritional properties and flavor of tomato during storage.

For the US bath systems, research has demonstrated that it is more challenging to obtain cavitation at higher frequencies, with US penetration inversely proportional to frequency, while dual-mode frequency can be associated with improved cavitation when compared with mono-mode frequency applications. In this manner, Zhou et al. [63] fabricated a closed-tank continuous-flow system that allowed for frequency and nominal power variation and observed that 25, 40, and $75 \mathrm{kHz}$ transducers dissipated 95, 85, and 45\% rated power, corresponding to intensities of 79.41, 68.95, and $42.36 \mathrm{~W} / \mathrm{L}$, respectively (Figure $2 \mathrm{~b}$ ). The use of agitation ensured spatial uniformity of US treatment, and the populations of E. coli O157:H7 on spinach leaves were reduced by 4.45, 4.21, and $2.42 \log \mathrm{CFU} / \mathrm{g}$, respectively, from 25, 40, and $75 \mathrm{kHz}$ transducers, suggesting that non-uniform cavitation from ultrasonic field variations may contribute to variations in microbial inactivation and cross-contamination in the US bath system. In a recent study, Mustapha et al. [20] showed that the application of dual-mode frequency of $20 / 40 \mathrm{kHz}$ during US treatment of tomato presented higher microbial reductions of 1.3-2.6 log CFU/g for mesophilic bacteria and molds and yeasts, compared with $<1 \log$ CFU/g obtained when mono-mode frequency of 20 or $40 \mathrm{kHz}$ was applied. There were no 
detrimental effects on the bioactive compounds and physicochemical properties of tomato during storage, substantiating the enhanced cavitation characterized by dual-mode frequency applications.

It has also been demonstrated that substances can be incorporated into samples from the US bath system for better effects. Yilmaz and Bilek [69] combined vacuum impregnation and US (72-840 W, $35 \mathrm{kHz}$ ) in custom-made equipment, observing that calcium and black carrot phenolics can be incorporated into apple tissues to produce natural colorant-fortified products without disturbing cellular integrity (Figure 2c). Treatment reduced psychrophilic and mesophilic bacteria on apples by 1.0-2.6 $\log \mathrm{CFU} / \mathrm{g}$ during storage and led to increases in firmness and bioactive compounds, while higher power levels resulted in apple cell rupture, which was evident from increased ion leakage in apple tissues. Wiktor et al. [70] showed that immersion treatment from a $40 \mathrm{kHz}, 180 \mathrm{~W}$ bath system presented apples with lower mass loss of $0.5-1.2 \%$, dry matter of $0.115 \mathrm{~kg} \mathrm{dm} / \mathrm{kg}$, higher bioactive compound contents, and less color change when compared with contact treatment from a $24 \mathrm{kHz}$, $100 \%$ amplitude ring sonotrode probe system. The surrounding water during immersion treatment played a significant role in water gain and cooling of apples, hence lower weight loss, while localized oxygen on apple tissue pores and enhanced enzymatic activities during contact treatment could degrade bioactive compounds. Although this may appear to suggest that treatment using the US bath system has shown a better quality of sample properties when compared with the US probe system, this does however need more detailed and careful comparison in terms of same usage of US energy frequency and intensity.

\subsection{Effects of US Technology on Microorganism Inactivation and Quality of Fruits and Vegetables}

Table 2 presents a summary of some studies that have applied US technology to inactivate microorganisms and subsequent effects on quality parameters for a number of fruits and vegetables. The majority of the applications were carried out in combination with sanitizers so as to avoid possible cross-contamination, since microorganisms are usually released into the wash water during US decontamination. However, among the individual US applications, Gani et al. [71] reported 2.0 and $1.2 \mathrm{log}$ reductions in bacterial counts and yeast and mold, respectively, in addition to retention in color, firmness, vitamin C, and antioxidant activity. Prolonged exposure time after $40 \mathrm{~min}, 33 \mathrm{kHz}$, and $60 \mathrm{~W}$ did not further extend shelf life but may have caused injuries to strawberry samples. In another study, the action of US at $25 \mathrm{kHz}$ and $26 \mathrm{~W} / \mathrm{L}$ was reported as similar to the actions of abiotic stress such as wounding in triggering and eliciting defense systems in Romaine lettuce [72]. A response mechanism was suggested for such actions (Figure 3a), and treated lettuce displayed enhanced antioxidant activity, higher firmness, delayed enzymatic browning, and absence of deterioration during storage. Preservative treatments are usually known to be associated with the degradation of important freshness-related attributes that define the quality of fresh produce. This perception needs to be critically considered, especially the effects on health-stimulating phytonutrients and other related compounds during the design and selection of processing parameters.

For combination applications, the synergistic effects of US and chemical sanitizers, surfactants, organic acids, and electrolyzed water for improved decontamination efficiency and enhanced quality attributes have been reported [10,73-84]. Increased efficiency was observed without synergistic effect, and also with both synergistic and antagonistic effects in some cases. Park et al. [79] reported antagonistic effects against Cronobacter sakazakii when US at $37 \mathrm{kHz}$ and $380 \mathrm{~W}$ was combined with $150 \mathrm{ppm}$ of $\mathrm{NaOCl}$. Although the plausible reason for antagonistic effect was not clear, synergistic combination mostly eliminated bacteria cells from the surface of lettuce and in the stomata, as observed in the scanning emission spectroscopy (Figure 3b), yielding $4.44 \log$ CFU/g reduction of C. sakazakii compared with $0.01-2.71 \log$ CFU/g reduction for individual applications of US and $\mathrm{NaOCl}$. These studies demonstrated that US alone was not greatly effective, even with long treatment time, while the cavitation effect of US detached microorganisms from fresh produce, especially at inaccessible regions, increasing their susceptibility to sanitizers. Thus, the chemical composition of the liquid in the US system can influence decontamination actions. The US system also promoted the rapid dispersion 
of organic matter, which increased their contact time with sanitizer constituents, leading to minimal residues in post-treatment solutions. The presence of microorganisms in treatment solutions were also very low and, in some cases, nonexistent, indicating that US and adequate sanitizer concentrations could prevent and/or reduce cross-contamination.

(a)
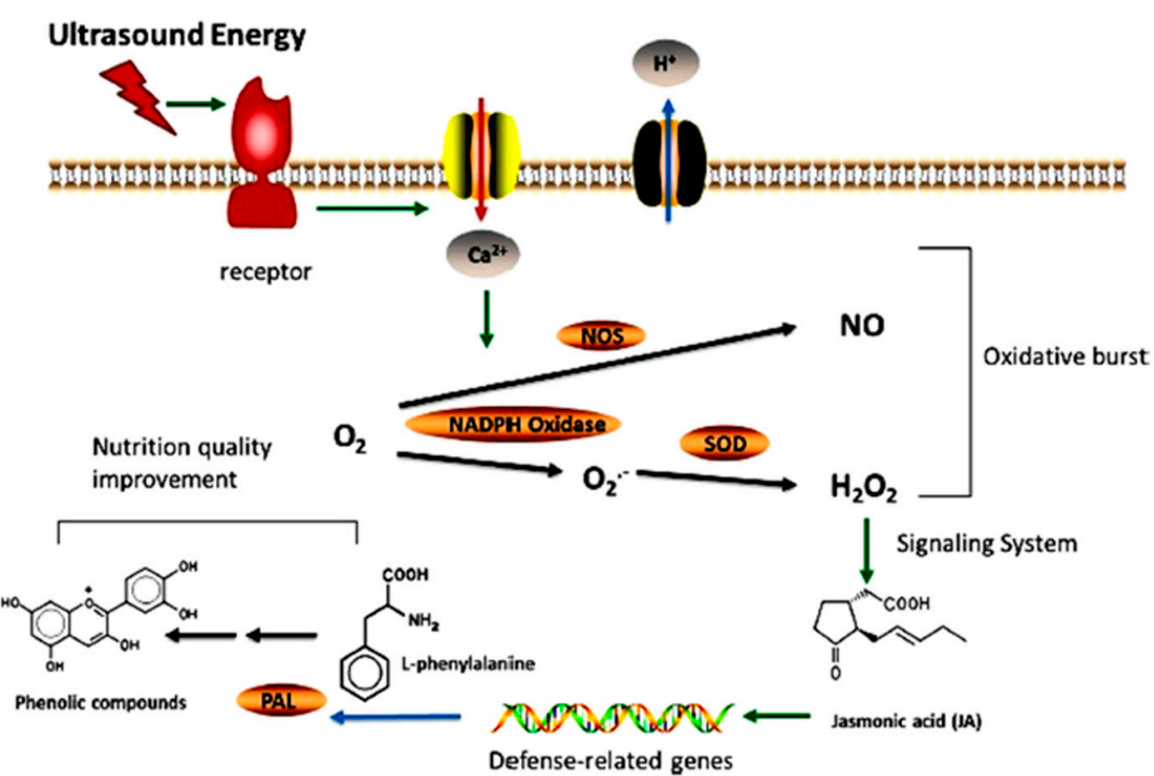

(b)

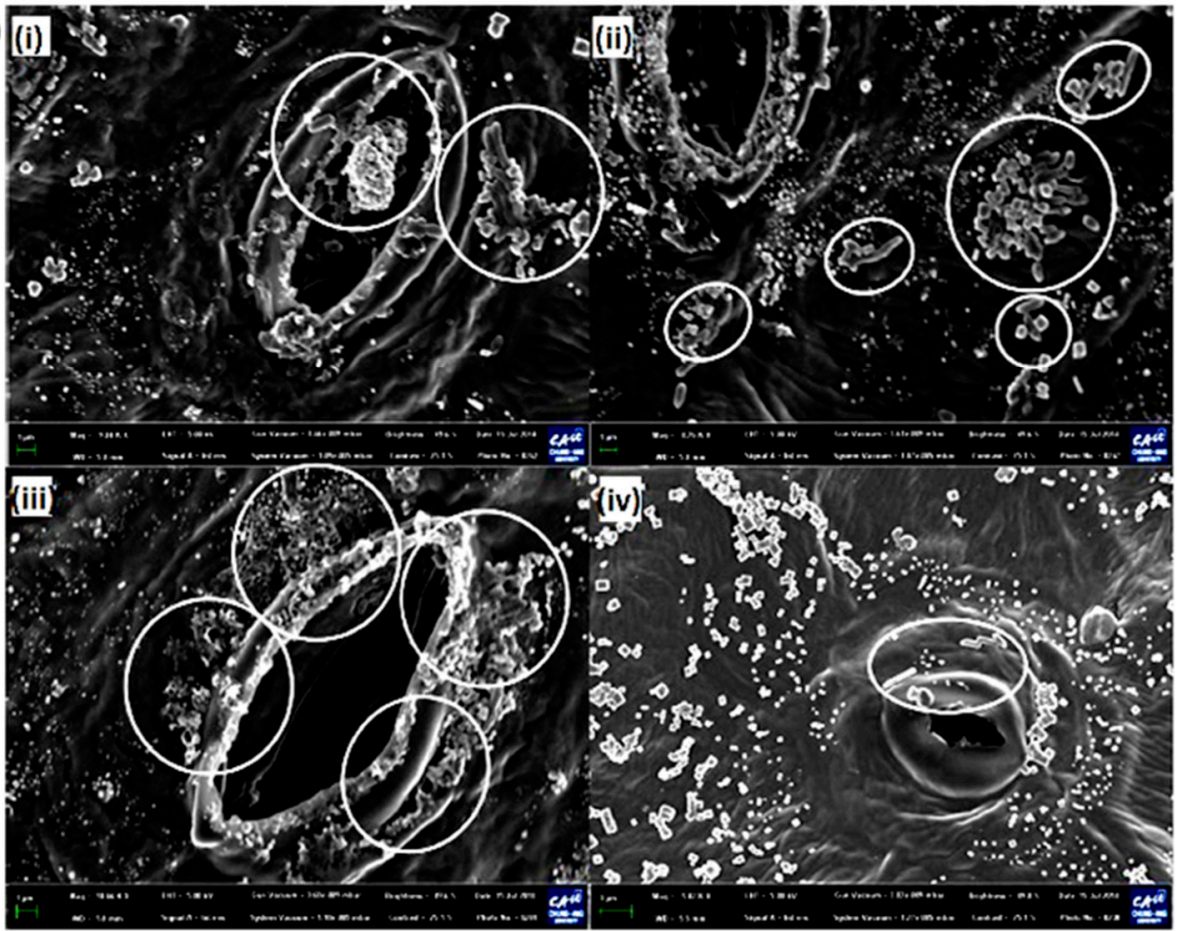

Figure 3. (a) Proposed mechanism of secondary metabolism response in Romaine lettuce during US. Reproduced with permission from Yu et al., Food and Bioprocess Technology; published by Springer Nature, 2016. (b) Field emission scanning electron microscopy of lettuce head showing aggregation and elimination of Cronobacter sakazakii during treatment: (i) control, (ii) US treatment, (iii) $\mathrm{NaOCl}$ treatment, and (iv) combined US and $\mathrm{NaOCl}$ treatment. Reproduced with permission from Park et al., Food Control; published by Elsevier, 2016. 
Table 2. List of fruits and vegetables treated with US technology.

\begin{tabular}{|c|c|c|c|c|}
\hline \multirow{2}{*}{$\begin{array}{c}\text { Fruit/ } \\
\text { Vegetable }\end{array}$} & \multirow{2}{*}{ Ultrasound Parameters } & \multicolumn{2}{|c|}{ Main Findings } & \multirow{2}{*}{ Sources } \\
\hline & & Quality Attributes & Microbial Log Reduction and Disease Incidence & \\
\hline \multirow{3}{*}{ Apple } & $170 \mathrm{kHz},+20 \mathrm{ppm} \mathrm{ClO} 2,360 \mathrm{~s}$ & \multirow{3}{*}{$\begin{array}{c}- \\
\text { Higher antioxidant and phenolic content } \\
\text { Increases in bioactive compounds, calcium, and } \\
\text { ion leakage }\end{array}$} & E. coli: 3.3 , S. enterica: 4.0 & [73] \\
\hline & $40 \mathrm{kHz}, 180 \mathrm{~W}$ & & - & [70] \\
\hline & $35 \mathrm{kHz}, 72-840 \mathrm{~W},+\mathrm{VI}$ & & Psychrophilic and mesophilic bacteria: 1.0-2.6 & [69] \\
\hline Asparagus & $\begin{array}{l}40 \mathrm{kHz}, 360 \mathrm{~W},+2 \% \text { acetic acid } \\
\quad+50 \mathrm{mg} / \mathrm{kg} \text { gibberellic acid }\end{array}$ & $\begin{array}{l}\text { Low weight loss; increased soluble solids, phenols, } \\
\text { ascorbic acid, and chlorophyll; inhibited PAL and } \\
\text { POD }\end{array}$ & Yeast and mold, total number of colonies: 2 & [85] \\
\hline \multirow[b]{2}{*}{ Cabbage } & $\begin{array}{l}32 \mathrm{kHz}, 10 \mathrm{~W} / \mathrm{L}, 600 \mathrm{~s}+ \\
\text { surfactant }\end{array}$ & - & E. coli: 2.91 & [74] \\
\hline & $\begin{array}{l}40 \mathrm{kHz}, 400 \mathrm{~W} / \mathrm{L}, 180 \mathrm{~s},+40^{\circ} \mathrm{C}+ \\
\text { SAEW + wash water }\end{array}$ & $\begin{array}{l}\text { Overall visual quality, browning, and off-odor } \\
\text { under acceptable limits }\end{array}$ & $\begin{array}{c}\text { Yeast and mold: } 2.5-3.24, \text { E. coli: } 2.6-3.32 \text {, total } \\
\text { bacteria count: } 2.54-3.97, \text { L. monocytogenes: } 2.8-3.11 \text {, } \\
\text { Enterobacteriaceae: } 3.66\end{array}$ & {$[75,86,87]$} \\
\hline \multirow[b]{2}{*}{ Cucumber } & $37 \mathrm{kHz}, 13.57 \mathrm{~W} / \mathrm{L},+\mathrm{PA}$ & \multirow{2}{*}{$\begin{array}{l}\text { Color, moisture content, and texture maintained } \\
\text { Improved cell wall integrity; retained ascorbic } \\
\text { acid; reduction in weight loss, firmness, and } \\
\text { soluble solids }\end{array}$} & C. sakazakii: $0.60,3.51$ & [76] \\
\hline & $\begin{array}{l}20 \mathrm{kHz}, 400 \mathrm{~W}, 226 \mathrm{~W} / \mathrm{cm}^{2} \\
300-600 \mathrm{~s}\end{array}$ & & $\begin{array}{l}\text { Yeast and mold: } 0.41-0.84 \text {, total number of colonies: } \\
\qquad 0.49-1.02\end{array}$ & [65] \\
\hline \multirow[b]{2}{*}{ Kiwifruit } & $30 \mathrm{kHz}, 368 \mathrm{~W} / \mathrm{cm}^{2},+\mathrm{NaOCl}$ & Reduced vitamin C, soluble solids, and firmness & Total bacteria count: 2.35 , yeast and mold: 1.36 & [88] \\
\hline & $\begin{array}{c}40 \mathrm{kHz}, 350 \mathrm{~W}, 600 \mathrm{~s}+ \\
\text { nano-ZnO coating + MAP }\end{array}$ & $\begin{array}{l}\text { Improved texture; low } \mathrm{CO}_{2} \text { and ethylene } \\
\text { production }\end{array}$ & - & [89] \\
\hline \multirow{9}{*}{ Lettuce } & $\begin{array}{c}32 \mathrm{kHz}, 10 \mathrm{~W} / \mathrm{L}, 600 \mathrm{~s}+ \\
\text { surfactant }\end{array}$ & - & S. Typhimurium: 2.7, E. coli: 2.11 & [74] \\
\hline & $\begin{array}{c}40 \mathrm{kHz}, 400 \mathrm{~W} / \mathrm{L}, 180 \mathrm{~s},+\mathrm{SAEW} \\
\text { + wash water }\end{array}$ & - & $\begin{array}{l}\text { Yeast and mold: } 2.25 \text {, total bacteria count: } 2.6, \text { E. coli: } \\
2.5-2.8, \text { L. monocytogenes: } 2.6\end{array}$ & [75] \\
\hline & $\begin{array}{c}40 \mathrm{kHz}, 30 \mathrm{~W} / \mathrm{L}, 300 \mathrm{~s},+ \text { organic } \\
\text { acids }\end{array}$ & Maintained color and textural properties & $\begin{array}{c}\text { E. coli: } 2.75, \text { S. Typhimurium: } 3.18, \text { L. monocytogenes: } \\
2.87\end{array}$ & [77] \\
\hline & $\begin{array}{c}37 \mathrm{kHz}, 30 \mathrm{~W} / \mathrm{L}, 3600 \mathrm{~s},+\mathrm{BPW}+ \\
24 \mathrm{~kJ} / \mathrm{m}^{2}, 1200 \mathrm{~s}\end{array}$ & - & $\begin{array}{c}\text { E coli: } 2.3 \text {, S. aureus: } 1.7, \text { S. Enteritidis: } 5.72, \text { L. innocua: } \\
\text { 1.88, HAdV: } 1.75-2.85\end{array}$ & {$[19,43]$} \\
\hline & $\begin{array}{c}26 \mathrm{kHz}, 200 \mathrm{~W}, 90 \mu \mathrm{m}+ \\
\text { essential oils }\end{array}$ & Increased electrolyte leakage & S. enterica: $1.68-3.08$, E. coli: $0.76-2.65$ & {$[15,66]$} \\
\hline & $25 \mathrm{kHz}, 26 \mathrm{~W} / \mathrm{L}, 60 \mathrm{~s}$ & Delayed browning; enhanced bioactive content & - & [72] \\
\hline & $\begin{array}{c}42 \mathrm{kHz}, 0.5 \mathrm{~W} / \mathrm{ml},+\mathrm{Cl}_{2}+ \\
\text { surfactants }\end{array}$ & $\begin{array}{c}\text { Higher values of color change and electrolyte } \\
\text { leakage }\end{array}$ & E. coli: 2.61, L. innocua: 2.23 , P. fluorescens: $1.10-2.10$ & {$[78]$} \\
\hline & $37 \mathrm{kHz}, 13.57 \mathrm{~W} / \mathrm{L},+\mathrm{NaClO}$ & $\mathrm{pH}$ and sugar content maintained & C. sakazakii: $0.58-4.44$ & [79] \\
\hline & $20 \mathrm{kHz}, 131.25 \mathrm{~W} / \mathrm{L}+\mathrm{NNEW}$ & - & E. coli: $4.4, S$. Typhimurium: 4.3 & [80] \\
\hline
\end{tabular}


Table 2. Cont

\begin{tabular}{|c|c|c|c|c|}
\hline \multirow{2}{*}{$\begin{array}{c}\text { Fruit/ } \\
\text { Vegetable }\end{array}$} & \multirow{2}{*}{ Ultrasound Parameters } & \multicolumn{2}{|c|}{ Main Findings } & \multirow{2}{*}{ Sources } \\
\hline & & Quality Attributes & Microbial Log Reduction and Disease Incidence & \\
\hline Melons & $40 \mathrm{kHz}, 120 \mathrm{~s},+1 \%$ lactic acid & - & E. coli: 2.5 , S. enterica Enteritidis: 3.1 & [81] \\
\hline Parsley & $\begin{array}{c}32 \mathrm{kHz}, 10 \mathrm{~W} / \mathrm{L}, 600 \mathrm{~s}+ \\
\text { surfactant }\end{array}$ & - & E. coli: 0.84 & [74] \\
\hline Peach & $40 \mathrm{kHz}, 600 \mathrm{~s}, 8.8 \mathrm{~W} / \mathrm{L}+\mathrm{SA}$ & Higher phenol content and enzyme activities & P. expansum: growth inhibition & [82] \\
\hline \multirow{3}{*}{ Pepper } & \multirow{3}{*}{$\begin{array}{c}35 \mathrm{kHz}, 21.4 \mathrm{~W} / \mathrm{L}, 120 \mathrm{~s}, 65^{\circ} \mathrm{C} \\
40 \mathrm{kHz}, 120 \mathrm{~s},+1 \% \text { lactic acid } \\
40 \mathrm{kHz}, 400 \mathrm{~W} / \mathrm{L}, \mathrm{SAEW}+\text { mild } \\
\text { heat }\end{array}$} & Improved firmness; color preserved & L innocua: 7.4 & [56] \\
\hline & & - & E. coli: 2.9 , S. enterica Enteritidis: 2.8 & [81] \\
\hline & & Color and firmness preserved & L. monocytogens, S. enterica: $1.0-3.0$ & [21] \\
\hline Plum & $\begin{array}{c}40 \mathrm{kHz}, 100 \mathrm{~W}, 600 \mathrm{~s},+40 \mathrm{mg} / \mathrm{L} \\
\mathrm{ClO}_{2}\end{array}$ & $\begin{array}{l}\text { Reduced respiration rate; maintained acidity, } \\
\text { flavonoid, and ascorbic acid }\end{array}$ & $\begin{array}{l}\text { Aerobic mesophilic and aerobic psychotropic bacteria, } \\
\text { yeast and mold: reduced counts }\end{array}$ & {$[8]$} \\
\hline Sesame leaf & $\begin{array}{c}40 \mathrm{kHz}, 400 \mathrm{~W} / \mathrm{L}, 180 \mathrm{~s},+ \text { SAEW } \\
\text { + wash water }\end{array}$ & - & Yeast and mold: 1.76, E. coli: 2.33, L. monocytogenes: 2.4 & [75] \\
\hline \multirow{2}{*}{ Spinach } & $\begin{array}{c}40 \mathrm{kHz}, 400 \mathrm{~W} / \mathrm{L}, 180 \mathrm{~s},+ \text { SAEW } \\
\text { + wash water }\end{array}$ & - & $\begin{array}{l}\text { Yeast and mold: 1.97, E. coli: 2.41, L. monocytogenes: } \\
2.49\end{array}$ & [75] \\
\hline & $25 \mathrm{kHz}, 79.41 \mathrm{~W} / \mathrm{L}, 60 \mathrm{~s}$ & - & $\begin{array}{l}\text { E. coli: } 4.45 \text {, total aerobic count: } 2.27 \text {, yeast and mold: } \\
\qquad 1.77\end{array}$ & [63] \\
\hline \multirow{7}{*}{ Strawberry } & $\begin{array}{c}32 \mathrm{kHz}, 10 \mathrm{~W} / \mathrm{L}, 600 \mathrm{~s}+ \\
\text { surfactant }\end{array}$ & ( & E. coli: 1.96 & [74] \\
\hline & $\begin{array}{c}20 \mathrm{kHz}, 30 \mathrm{~W} / \mathrm{L}, 300 \mathrm{~s},+\mathrm{O}_{3}+ \\
\mathrm{ClO}_{2}\end{array}$ & $\begin{array}{c}\text { Maintained quality and physicochemical } \\
\text { properties }\end{array}$ & B. cinera: growth and decay incidence inhibition & {$[10]$} \\
\hline & $35 \mathrm{kHz}, 21.4 \mathrm{~W} / \mathrm{L}, 120 \mathrm{~s}, 65^{\circ} \mathrm{C}$ & $\begin{array}{c}\text { Improved firmness; anthocyanin and color } \\
\text { retained }\end{array}$ & Total mesophiles: 8.24 & [56] \\
\hline & $40 \mathrm{kHz}, 250-350 \mathrm{~W}, 600 \mathrm{~s}$ & $\begin{array}{c}\text { Improved firmness, soluble solids, acidity, and } \\
\text { vitamin C }\end{array}$ & Total bacteria: $1.9-2.42$, yeast and mold: $1.35-2.45$ & [90] \\
\hline & $40 \mathrm{kHz}, 24 \mathrm{~W} / \mathrm{L}, 600 \mathrm{~s}+\mathrm{SAEW}$ & Maintained physicochemical properties & Total aerobic bacteria, yeast and mold: 1.29 & [83] \\
\hline & $\begin{array}{c}37 \mathrm{kHz}, 30 \mathrm{~W} / \mathrm{L}, 3600 \mathrm{~s},+\mathrm{BPW}+ \\
24 \mathrm{~kJ} / \mathrm{m}^{2}, 1200 \mathrm{~s}\end{array}$ & & $\begin{array}{c}\text { E coli: } 3.04, \text { S. aureus: } 2.42, \text { S. Enteritidis: } 5.52, \\
\text { L. innocua: } 6.12, \text { HAdV: } 2.73-3.98\end{array}$ & {$[19,43]$} \\
\hline & $33 \mathrm{kHz}, 60 \mathrm{~W}$ & $\begin{array}{c}\text { Maintained physicochemical and antioxidant } \\
\text { properties }\end{array}$ & Total bacteria count: 2.0 , yeast and mold: 1.22 & [71] \\
\hline
\end{tabular}


Table 2. Cont.

\begin{tabular}{|c|c|c|c|c|}
\hline \multirow{2}{*}{$\begin{array}{c}\text { Fruit/ } \\
\text { Vegetable }\end{array}$} & \multirow{2}{*}{ Ultrasound Parameters } & \multicolumn{2}{|c|}{ Main Findings } & \multirow{2}{*}{ Sources } \\
\hline & & Quality Attributes & Microbial Log Reduction and Disease Incidence & \\
\hline \multirow{5}{*}{ Tomato } & $20 \mathrm{kHz}, 131.25 \mathrm{~W} / \mathrm{L},+\mathrm{NNEW}$ & - & E. coli, S. Typhimurium: no detection & [80] \\
\hline & $45 \mathrm{kHz}, 1140 \mathrm{~s}$ & Enhanced phenols; delayed color development & Total microbial count, yeast and mold: reduced count & [91] \\
\hline & $40 \mathrm{kHz}, 24 \mathrm{~W} / \mathrm{L}, 600 \mathrm{~s}+\mathrm{SAEW}$ & Soluble solids; acidity and vitamin C maintained & Total aerobic bacteria: 1.77, yeast and mold: 1.50 & [83] \\
\hline & $45 \mathrm{kHz}, 600 \mathrm{~s}+$ peracetic acid & - & $\begin{array}{c}\text { S. enterica: } 3.90 \text {, yeast and mold: } 3.4 \text {, aerobic } \\
\text { mesophile: } 4.44\end{array}$ & [84] \\
\hline & $\begin{array}{c}37 \mathrm{kHz}, 30 \mathrm{~W} / \mathrm{L}, 600 \mathrm{~s},+\mathrm{BPW}+ \\
24 \mathrm{~kJ} / \mathrm{m}^{2}, 1200 \mathrm{~s}\end{array}$ & - & HAdV: 1.20-2.61 & [43] \\
\hline Watercress & $35 \mathrm{kHz}, 21.4 \mathrm{~W} / \mathrm{L}, 120 \mathrm{~s}, 65^{\circ} \mathrm{C}$ & Improved firmness; pronounced color difference & Total coliforms: 8.24 & {$[56]$} \\
\hline Zucchini & $\begin{array}{l}20 \mathrm{kHz}+0.165-8.2 \mathrm{~kJ} / \mathrm{m}^{2}+ \\
\text { blanching }\left(60-90^{\circ} \mathrm{C}\right)\end{array}$ & - & Enterococcus faecalis, Deinococcus radiodurans: 1-3 & [26] \\
\hline
\end{tabular}

VI: vacuum impregnation, BPW: buffered peptone water, PAL: phenylalanine ammonia lyase, PA: peroxyacetic acid, SA: salicylic acid, POD: peroxidase, SAEW: slightly acidic electrolyzed water, NNEW: near neutral electrolyzed water, MAP: modified atmosphere packaging, HAdV: human adenovirus. 
The systems for nano- $\mathrm{ZnO}$ coating application on kiwifruit after US treatment have also been evaluated [89]. Although individual US treatment of kiwifruit was somewhat effective, sequential application of US at $40 \mathrm{kHz}, 350 \mathrm{~W}$, and $1.2 \mathrm{~g} / \mathrm{L}$ nano- $\mathrm{ZnO}$ coating was more effective in senescence delay, mass and firmness loss reduction, and storage life extension. The addition of mild heat to US treatment have also been explored, where a more pronounced effect of US $(35 \mathrm{kHz}, 120 \mathrm{~W}$, and $21.4 \mathrm{~W} / \mathrm{L})$ was reported at $65^{\circ} \mathrm{C}$ on red bell pepper, watercress, and strawberry, with improved quality retention and enhanced reductions of 7.43, 8.24, and $8.10 \mathrm{log}$ CFU/g for L. innocua, total mesophiles, and total coliforms, respectively [56]. Similarly, the efficacy of US at $40 \mathrm{kHz}, 400 \mathrm{~W} / \mathrm{L}$ combined with SAEW was also enhanced at 40 and $60{ }^{\circ} \mathrm{C}$, respectively, for fresh cut kale and bell pepper $[21,86,87]$. Browning and off-odor were under acceptable limits for fresh cut kale, while hardness and color parameters for control and treated samples were not significantly different for bell pepper. Enhanced bactericidal efficacy led to 3.32, 3.11, 3.00, 3.97, 3.66, 3.62, and $3.24 \log$ CFU/g reductions in E. coli, L. monocytogenes, S. Typhimurium, total bacterial counts, Enterobacteriaceae, Pseudomonas spp., and yeast and mold counts, respectively.

\section{Combination of UV-C Radiation and US Technology}

Some studies have begun to examine the development of hurdle techniques involving UV-C radiation and US technology, either in sequential or simultaneous application. Sequential application involves treatment with one technology immediately followed by others and has shown improved microbial reductions and minimized quality changes in zucchini squash [26]. Alternative blanching treatments of UV-C radiation $\left(1.17-8.2 \mathrm{~kJ} / \mathrm{m}^{2}\right)$ followed by thermosonication $\left(20 \mathrm{kHz}, 90^{\circ} \mathrm{C}\right)$ induced $3 \mathrm{log}$ reductions in Enterococcus faecalis and Deinococcus radiodurans, compared with 1 log reduction achieved from individual treatment with UV-C radiation. Birmpa et al. [19] demonstrated that sequential application of US at $30 \mathrm{~W} / \mathrm{L}$ followed by UV-C radiation at $24 \mathrm{~kJ} / \mathrm{m}^{2}$ evoked better $\log$ reductions (2-3 log) of human adenovirus ( $\mathrm{hAdVs}$ ) with less processing time, compared with individual results of UV-C radiation $(2.13,0.92,1.25 \mathrm{log})$ and $U S(0.85,0.36,0.53 \mathrm{log})$ on lettuce, cherry tomato, and strawberry, respectively.

Simultaneous application, on the other hand, applies both technologies at the same time with enhanced results in disinfection efficacy and functional properties. A constant US intensity of $13.87 \mathrm{~W} / \mathrm{L}$ from a $40 \mathrm{kHz}, 1 \mathrm{~kW}$ transducer and UV-C radiation dosage of $0.72-10.76 \mathrm{~kJ} / \mathrm{m}^{2}$ revealed increasing reduction in the population of total aerobic bacteria on tomato and up to $2.33 \mathrm{log}$ reduction, while yeast and mold were undetected at higher dosage levels [22]. Enhanced biosynthesis and extractability of phytochemicals were also reported in tomato, with 36, 60,30, and 90\% increases in antioxidant activities, vitamin C, total phenols, and lycopene contents, respectively [1,92]. The combined effects of UV-C radiation and US cavitation were observed to disrupt the structural integrity of macromolecules and chemical bonds of tomato phytochemicals, which stimulated their accumulation and facilitated their extraction. Collectively, these few studies present the potential of a hurdle technology involving UV-C radiation and US technology for the postharvest decontamination of fruits and vegetables, with this area of focus warranting further exploration.

The theory elucidating the mechanism of the synergy between US technology and UV-C radiation can be explained from their individual mechanisms of operation. It is possible that the resultant mechanical effect of the collapse of transient cavitation from US technology, which includes high heating and cooling rate $\left(10^{9} \mathrm{~K} / \mathrm{s}\right)$, shock wave formation, high temperature $(5000 \mathrm{~K})$, and pressure $(1000 \mathrm{~atm})$, ruptures microbial cell envelopes [93]. The ruptured cell envelopes then facilitate access of UV-C radiation to light-sensitive DNA of the microorganisms within a short processing time. The formation of cyclobutane thymine dimmers from the action of UV-C radiation combined with chemical effects of $\mathrm{OH}^{-}$and $\mathrm{H}^{+}$species formation from US technology eventually offers a more potent bactericidal effect that is capable of depleting microbial growth, leading to the eventual death of microorganisms $[42,93]$. However, this theory needs to be properly tested from more studies and relevant tools. 


\section{Future Perspectives and Industrial Relevance}

The low penetrating capacity of UV-C radiation into opaque substances, high energy consumption, and long treatment time associated with US technology has limited their individual usage. Thus, research in the applications of UV-C radiation and US technology for postharvest decontamination of fruits and vegetables is focused on hurdle technology of combination applications, which have shown enhanced decontamination efficiency. The hurdle technology has shown potential of overcoming limitations and harnessing advantages of each individual technology. As studies reported on this hurdle technology are relatively few, it is necessary to have more validation towards achieving industrial-scale applications. Scale-up studies to larger proportions would reveal important considerations to ensure uniformity of US cavitation and UV-C exposure on food surfaces due to variations in ultrasonic field and non-penetrative ability of UV-C radiation, which have been observed as the most important challenges to the commercialization of US technology and UV-C radiation for fresh produce decontamination [63,94]. The use of agitation in free-flowing US baths and application of mixed-mode US frequencies can reduce standing-wave effects and creation of different cavitation bubble size to ensure uniform cavitation [20,63]. Wide variations in UV-C radiation intensity can be reduced so that energy reaches the samples more effectively [26]. The radiochromic film dosimetry approach could also be introduced to UV-C treatment to measure or evaluate exposure of radiation dose. Film dosimetry is reportedly associated with measuring and verifying the dosage level on food substances during irradiation $[94,95]$. Once non-uniformity of irradiation or wide variations in dose is established, a system to rotate irradiated samples as described by Yan et al. [26] can be introduced to ensure UV-C dosage uniformity on the samples for improved efficiency, especially in high loading industrial applications. For combination approaches of US technology and UV-C radiation, we can incorporate sanitizer solutions as the washing medium in US baths lined with UV-C radiation lamps to enhance efficiency and reduce cross-contamination. The heat generated from simultaneous combination energies, which may cause dehydration and damage the appearance of fresh produce, may be overcome by incorporating a water circulatory system that simultaneously introduces and drains water in the tank to help control temperature rise and ensure minimal cross-contamination. Identification of important factors influencing the decontamination process can be enhanced through better understanding of microbes' behavior where more accurate inactivation of target microorganisms can assist optimization of the process parameters for cost-effective practical applications.

\section{Conclusions}

The research on the postharvest decontamination of fruits and vegetables is rapidly evolving due to increased safety awareness and consumer demands for minimally processed foods with fresh-like characteristics. UV-C radiation and US technology have presented encouraging results in postharvest decontamination of fresh produce with minimal effects on quality characteristics. However, long exposure time, high US energy consumption, and limited penetration capability of UV-C radiation have plagued research in these areas. The potential for synergistic or complementary effects for improved efficiency have also been established when UV-C radiation or US technology is applied in combination with other antimicrobial techniques. The hurdle technology involving UV-C radiation and US technology offer substitute benefits towards ensuring overall safety and wholesomeness of fruits and vegetables in comparison with individual applications or their combinations with conventional approaches. More studies are required on this hurdle technology, while scale-up and optimization of the process will provide opportunities for industry-led collaborations and chart the path towards effective commercialization.

Author Contributions: Conceptualization, O.J.E. and N.L.C.; investigation, O.J.E.; resources, O.J.E. and N.L.C.; data curation, O.J.E.; writing-original draft preparation, O.J.E.; writing—review and editing, N.L.C.; supervision, N.L.C., Y.A.Y., and R.S.; project administration, N.L.C.; funding acquisition, O.J.E and N.L.C. All authors have read and agreed to the published version of the manuscript. 
Funding: This research was funded by Universiti Putra Malaysia, grant number GP-I/2014/9439000, and the first author was funded by Niger Delta Development Commission, Nigeria (NDDC/DEHSS/2014PGFS/AKS/014), for postgraduate study.

Acknowledgments: The authors are grateful to Daniel Onwude for providing some insights and discussion of the manuscript.

Conflicts of Interest: The authors declare no conflict of interest.

\section{References}

1. Esua, O.J.; Chin, N.L.; Yusof, Y.A.; Sukor, R. Effects of simultaneous UV-C radiation and ultrasonic energy postharvest treatment on bioactive compounds and antioxidant activity of tomatoes during storage. Food Chem. 2019, 270, 113-122. [CrossRef] [PubMed]

2. Dyshlyuk, L.; Babich, O.; Prosekov, A.; Ivanova, S.; Pavsky, V.; Chaplygina, T. The effect of postharvest ultraviolet irradiation on the content of antioxidant compounds and the activity of antioxidant enzymes in tomato. Heliyon 2020, 6, e03288. [CrossRef] [PubMed]

3. Gustavsson, J.; Cederberg, C.; Sonesson, U.; van Otterdijk, R.; Meybeck, A. Global Food Losses and Food Waste: Extent, Causes and Prevention. Food and Agricultural Organisation of the United Nations, 2011. Available online: http://www.fao.org/fileadmin/user_upload/suistainability/pdf/Global_Food_Losses_and_ Food_Waste.pdf (accessed on 2 March 2016).

4. Scallan, E.; Hoekstra, R.M.; Angulo, F.J.; Tauxe, R.V.; Widdowson, M.-A.; Roy, S.L.; Jones, J.L.; Griffin, P.M. Foodborne illness acquired in the United States-major pathogens. Emerg. Infect. Dis. 2011, 17, 7-15. [CrossRef] [PubMed]

5. Kirk, M.D.; Pires, S.M.; Black, R.E.; Caipo, M.; Crump, J.A.; Devleesschauwer, B.; Dopfer, D.; Fazil, A.; Fischer-Walker, C.L.; Hald, T.; et al. World Health Organization estimates of the global and regional disease burden of 22 foodborne bacterial, protozoal, and viral diseases, 2010: A data synthesis. PLoS Med. 2015, 12, e1001921. [CrossRef]

6. Esua, O.J.; Chin, N.L.; Yusof, Y.A.; Sukor, R. Antioxidant bioactive compounds and spoilage microorganisms of wax apple (Syzygium samarangense) during room temperature storage. Int. J. Fruit Sci. 2017, 17, 188-201. [CrossRef]

7. Food and Agricultural Organisation of the United Nations. Available online: http://www.fao.org/3/ CA1397EN/ca1397en.pdf (accessed on 15 January 2019).

8. Chen, Z.; Zhu, C. Combined effects of aqueous chlorine dioxide and ultrasonic treatments on postharvest storage quality of plum fruit (Prunus salicina L.). Postharvest Biol. Technol. 2011, 61, 117-123. [CrossRef]

9. Phungamngoen, C.; Chiewchan, N.; Devahastin, S. Effects of various pretreatments and drying methods on Salmonella resistance and physical properties of cabbage. J. Food Eng. 2013, 115, 237-244. [CrossRef]

10. Aday, M.S.; Caner, C. Individual and combined effects of ultrasound, ozone and chlorinedioxide on strawberry storage life. LWT Food Sci. Technol. 2014, 57, 344-351. [CrossRef]

11. Martinez-Hernandez, G.B.; Navarro-Rico, J.; Gomez, P.A.; Oton, M.; Artes, F.; Artes-Hernandez, F. Combined sustainable sanitising treatments to reduce Escherichia coli and Salmonella Enteritidis growth on fresh-cut kalian-hybrid broccoli. Food Control 2015, 47, 312-317. [CrossRef]

12. Olosunde, W.A.; Aremu, A.K.; Onwude, D.I. Development of a solar powered evaporative cooling storage system for tropical fruits and vegetables. J. Food Process. Preserv. 2016, 40, 279-290. [CrossRef]

13. Tawema, P.; Han, J.; Vu, K.D.; Salmieri, S.; Lacroix, M. Antimicrobial effects of combined UV-C or gamma radiation with natural antimicrobial formulations against Listeria monocytogenes, Escherichia coli O157:H7, and total yeasts/molds in fresh cut cauliflower. LWT Food Sci. Technol. 2016, 65, 451-456. [CrossRef]

14. Dziedzic, E.; Blaszczyk, J.; Bieniasz, M.; Dziadek, K.; Kopec, A. Effect of modified (MAP) and controlled atmosphere (CA) storage on the quality and bioactive compounds of blue honeysuckle fruits (Lonicera caerulea L.). Sci. Hortic. 2020, 265, 109226. [CrossRef]

15. Millan-Sango, D.; Garroni, E.; Farrugia, C.; Van Impe, J.F.M.; Valdramidis, V.P. Determination of the efficacy of ultrasound combined with essential oils on the decontamination of Salmonella inoculated lettuce leaves. LWT Food Sci. Technol. 2016, 73, 80-87. [CrossRef] 
16. Park, S.-H.; Kang, J.-W.; Kang, D.-H. Inactivation of foodborne pathogens on fresh produce by combined treatment with UV-C radiation and chlorine dioxide gas, and mechanisms of synergistic inactivation. Food Control 2018, 92, 331-340. [CrossRef]

17. Lu, C.; Ding, J.; Park, H.K.; Feng, H. High intensity ultrasound as a physical elicitor affects secondary metabolites and antioxidant capacity of tomato fruits. Food Control 2020, 113, 107176. [CrossRef]

18. Darras, A.I.; Tsikaloudakis, G.; Lycoskoufis, I.; Dimitriadis, C.; Karamousantas, D. Low doses of UV-C irradiation affects growth, fruit yield and photosynthetic activity of tomato plants. Sci. Hortic. 2020, 267, 109357. [CrossRef]

19. Birmpa, A.; Bellou, M.; Kokkinos, P.; Vantarakis, A. Effect of nonthermal, conventional, and combined disinfection technologies on the stability of human adenoviruses as fecal contaminants on surfaces of fresh ready-to-eat products. J. Food Prot. 2016, 79, 454-462. [CrossRef]

20. Mustapha, A.T.; Zhou, C.; Wahia, H.; Amanor-Atiemoh, R.; Otu, P.; Qudus, A.; Fakayode, O.A.; Ma, H. Sonozonation: Enhancing the antimicrobial efficiency of aqueous ozone washing techniques on cherry tomato. Ultrason. Sonochem. 2020, 64, 105059. [CrossRef] [PubMed]

21. Luo, K.; Oh, D.-H. Inactivation kinetics of Listeria monocytogenes and Salmonella enterica serovar Typhimurium on fresh-cut bell pepper treated with slightly acidic electrolyzed water combined with ultrasound and mild heat. Food Microbiol. 2016, 53, 165-171. [CrossRef] [PubMed]

22. Esua, O.J.; Chin, N.L.; Yusof, Y.A. Simultaneous UV-C and ultrasonic energy treatment for disinfection of tomatoes and its antioxidant properties. J. Adv. Agric. Technol. 2018, 5, 209-214. [CrossRef]

23. Collazo, C.; Noguera, V.; Aguilo-Aguayo, I.; Abadias, M.; Colas-Meda, P.; Nicolau, I.; Vinas, I. Assessing water-assisted UV-C light and its combination with peroxyacetic acid and Pseudomonas graminis CPA-7 for the inactivation and inhibition of Listeria monocytogenes and Salmonella enterica in fresh-cut 'Iceberg' lettuce and baby spinach leaves. Int. J. Food Microbiol. 2019, 297, 11-20. [CrossRef]

24. Langcake, P.; Pryce, R.J. The production of resveratrol and the viniferins by grapevines in response to ultraviolet irradiation. Phytochemistry 1977, 16, 1193-1196. [CrossRef]

25. Artes, F.; Allende, A. Processing lines and alternative preservation techniques to prolong the shelf-life of minimally fresh processed leafy vegetables. Europ. J. Hort. Sci. 2005, 70, 231-245.

26. Yan, R.; Mattheis, J.; Gurtler, J.; Sites, J.; Fan, X. UV-C inactivation of Escherichia coli and dose uniformity on apricot fruit in a commercial setting. Postharvest Biol. Technol. 2014, 95, 46-49. [CrossRef]

27. Taze, B.H.; Unluturk, S. Effect of postharvest UV-C treatment on the microbial quality of 'Salak' apricot. Sci. Hortic. 2018, 233, 370-377. [CrossRef]

28. Mukhopadhyay, S.; Ukuku, D.O.; Juneja, V.; Fan, X. Effects of UV-C treatment on inactivation of Salmonella enterica and Escherichia coli $\mathrm{O} 157: \mathrm{H7}$ on grape tomato surface and stem scars, microbial loads, and quality. Food Control 2014, 44, 110-117. [CrossRef]

29. Lim, W.; Harrison, M.A. Effectiveness of UV light as a means to reduce Salmonella contamination on tomatoes and food contact surfaces. Food Control 2016, 66, 166-173. [CrossRef]

30. Neves, F.I.G.; Silva, C.L.M.; Vieira, M.C. Combined pre-treatments effects on zucchini (Cucurbita pepo L.) squash microbial load reduction. Int. J. Food Microbiol. 2019, 305, 108257. [CrossRef]

31. Bermudez-Aguirre, D.; Barbosa-Canovas, G.V. Disinfection of selected vegetables under non-thermal treatments: Chlorine, acid citric, ultraviolet light and ozone. Food Control 2013, 29, 82-90. [CrossRef]

32. Cote, S.; Rodoni, L.; Miceli, E.; Concellon, A.; Civello, P.M.; Vincente, A.R. Effect of radiation intensity on the outcome of postharvest UV-C treatments. Postharvest Biol. Technol. 2013, 83, 83-89. [CrossRef]

33. Adhikari, A.; Syamaladevi, R.M.; Killinger, K.; Sablani, S.S. Ultraviolet-C light inactivation of Escherichia coli O157:H7 and Listeria monocytogenes on organic fruit surfaces. Int. J. Food Microbiol. 2015, 210, 136-142. [CrossRef]

34. Syamaladevi, R.M.; Lu, X.; Sablani, S.S.; Insan, S.K.; Adhikari, A.; Killinger, K.; Rasco, B.; Dhingra, A.; Bandyopadhyay, A.; Annapure, U. Inactivation of Eschrichia coli population on fruit surfaces using UVC light: Influence on fruit surface characteristics. Food Bioproc. Tech. 2013, 6, 2959-2973. [CrossRef]

35. Nigro, F.; Ippolito, A.; Lattanzio, V.; Di Venere, D.; Salerno, M. Effect of ultraviolet -C light on postharvest decay of strawberry. J. Plant. Pathol. 2000, 82, 29-37.

36. Alegria, C.; Pinheiro, J.; Duthoit, M.; Goncalves, E.M.; Moldao-Martins, M.; Abreu, M. Fresh-cut carrot (cv. Nantes) quality as affected by abiotic stress (heat shock and UV-C irradiation) pre-treatments. LWT Food Sci. Technol. 2012, 48, 197-203. [CrossRef] 
37. Yun, J.; Yan, R.; Fan, X.; Gurtler, J.; Phillips, J. Fate of E. coli O157:H7, Salmonella spp. and potential surrogate bacteria on apricot fruit, following exposure to UV-C light. Int. J. Food Microbiol. 2013, 166, 356-363. [CrossRef]

38. Graca, A.; Salazar, M.; Quintas, C.; Nunesaday, C. Low dose UV-C illumination as an eco-innovative disinfection system on minimally processed apples. Postharvest Biol. Technol. 2013, 85, 1-7. [CrossRef]

39. George, D.S.; Razali, Z.; Santhirasegaram, V.; Somasundram, C. Effect of postharvest ultraviolet-C treatment on the proteome changes in fresh cut mango (Mangifera indica L. cv. Chokanan). J. Sci. Food Agric. 2016, 98, 2851-2860. [CrossRef] [PubMed]

40. Wang, D.; Chen, L.; Ma, Y.; Zhang, M.; Zhao, Y.; Zhao, X. Effect of UV-C treatment on the quality of fresh-cut lotus (Nelumbo nucifera Gaertn.) root. Food Chem. 2019, 278, 659-664. [CrossRef]

41. Pinheiro, J.; Alegria, C.; Abreu, M.; Goncalves, E.M.; Silva, C.L.M. Use of UV-C postharvest treatment for extending fresh whole tomato (Solanum lycopersicum, cv. Zinac) shelf-life. J. Food Sci. Technol. 2015, 52, 5066-5074. [CrossRef]

42. Sommers, C.H.; Sites, J.E.; Musgrove, M. Ultraviolet light (254 nm) inactivation of pathogens on foods and stainless steel surfaces. J. Food Saf. 2010, 30, 470-479. [CrossRef]

43. Birmpa, A.; Sfika, V.; Vantarakis, A. Ultraviolet light and ultrasound as non-thermal treatments for the inactivation of microorganisms in fresh ready-to-eat foods. Int. J. Food Microbiol. 2013, 167, 96-102. [CrossRef] [PubMed]

44. Gomez, P.L.; Alzamora, S.M.; Castadhikariro, M.A.; Salvatori, D.M. Effect of ultraviolet-C light dose on quality of cut-apple: Microorganism, color and compression behavior. J. Food Eng. 2010, 98, 60-70. [CrossRef]

45. Perkins-Veazie, P.; Collins, J.K.; Howard, L. Blueberry fruit response to postharvest application of ultraviolet radiation. Postharvest Biol. Technol. 2008, 47, 280-285. [CrossRef]

46. Kim, C.; Hung, Y.C. Inactivation of E. coli O157:H7 on blueberries by electrolyzed water, ultraviolet light, and ozone. J. Food Sci. 2012, 77, 206-211. [CrossRef] [PubMed]

47. Martinez-Hernandez, G.B.; Artes-Hernandez, F.; Gomez, P.A.; Formica, A.C.; Artes, F. Combination of electrolysed water, UV-C and super-atmospheric $\mathrm{O}_{2}$ packaging for improving fresh-cut broccoli quality. Postharvest Biol. Technol. 2013, 76, 125-134. [CrossRef]

48. Jemni, M.; Gomez, P.A.; Souza, M.; Chaira, N.; Ferchichi, A.; Oton, M.; Artes, F. Combined effect of UV-C, ozone and electrolysed water for keeping overall quality of date palm. LWT Food Sci. Technol. 2014, 59, 649-655. [CrossRef]

49. Freitas, P.M.; Lopez-Galvez, F.; Tudela, J.A.; Gil, M.I.; Allende, A. Postharvest treatment of table grapes with ultraviolet-C and chitosan coating preserves quality and increases stilbene content. Postharvest Biol. Technol. 2015, 105, 51-57. [CrossRef]

50. Santo, D.; Graca, A.; Nunes, C.; Quintas, C. Escherichia coli and Cronobacter sakazakii in Tommy Atkins minimally processed mangos: Survival, growth and effect of UV-C and electrolyzed water. Food Microbiol. 2018, 70, 49-54. [CrossRef]

51. Manzocco, L.; Da Pieve, S.; Maifreni, M. Impact of UV-C light on safety and quality of fresh-cut melon. Innov. Food Sci. Emerg. Technol. 2011, 12, 13-17. [CrossRef]

52. Artes-Hernandez, F.; Robles, P.A.; Gomez, P.A.; Tomas-Callejas, A.; Artes, F. Low UV-C illumination for keeping overall quality of fresh-cut watermelon. Postharvest Biol. Technol. 2010, 55, 114-120. [CrossRef]

53. Syamaladevi, R.M.; Lupien, S.L.; Bhunia, K.; Sablani, S.S.; Dugan, F.; Rasco, B.; Killinger, K.; Dhinger, A.; Ross, C. UV-C light inactivation kinetics of Penicillium expansum on pear surfaces: Influence on physicochemical and sensory quality during storage. Postharvest Biol. Technol. 2014, 87, 27-32. [CrossRef]

54. Schenk, M.; Guerrero, S.; Alzamora, S.M. Response of some microorganisms to ultraviolet treatment on fresh-cut pear. Food Bioproc. Tech. 2008, 1, 384-392. [CrossRef]

55. Graca, A.; Santo, D.; Quintas, C.; Nunes, C. Growth of Escherichia coli, Salmonella enterica and Listeria spp., and their inactivation using ultraviolet energy and electrolyzed water, on 'Rocha' fresh-cut pears. Food Control 2017, 77, 41-49. [CrossRef]

56. Alexandre, E.M.C.; Santos-Pedro, D.M.; Brandao, T.R.S.; Silva, C.L.M. Study on thermosonication and ultraviolet radiation processes as an alternative to blanching for some fruits and vegetables. Food Bioproc. Tech. 2011, 4, 1012-1019. [CrossRef] 
57. Manzocco, L.; Plazzotta, S.; Maifreni, M.; Calligaris, S.; Anese, M.; Nicoli, M.C. Impact of UV-C light on storage quality of fresh-cut pineapple in two different packages. LWT Food Sci. Technol. 2016, 65, 1138-1143. [CrossRef]

58. Kim, H.-G.; Song, K.B. Combined treatment with chlorine dioxide gas, fumaric acid, and ultraviolet-C light for inactivating Escherichia coli O157:H7 and Listeria monocytogenes inoculated on plums. Food Control 2017, 71, 371-375. [CrossRef]

59. Lopez-Rubira, V.; Conesa, A.; Allende, A.; Artes, F. Shelf life and overall quality of minimally processed pomegranate arils modified atmosphere packaged and treated with UV-C. Postharvest Biol. Technol. 2005, 37, 174-185. [CrossRef]

60. Artes-Hernandez, F.; Escalona, V.H.; Robles, P.A.; Martinez-Hernandez, G.B.; Artes, F. Effect of UV-C radiation on quality of minimally processed spinach leaves. J. Sci. Food Agric. 2009, 89, 414-421. [CrossRef]

61. Choi, D.S.; Park, S.H.; Choi, S.R.; Kim, J.S.; Chun, H.H. The combined effects of ultraviolet-C irradiation and modified atmosphere packaging for inactivating Salmonella enterica serovar Typhimurium and extending the shelf life of cherry tomatoes during cold storage. Food Packag Shelf Life 2015, 3, 19-30. [CrossRef]

62. Mansourbahmani, S.; Ghareyazie, B.; Kalatejari, S.; Mohammadi, R.S.; Zarinnia, V. Effect of post-harvest UV-C irradiation and calcium chloride on enzymatic activity and decay of tomato (Lycopersicon esculentum L.) fruit during storage. J. Integr. Agric. 2017, 16, 2093-2100. [CrossRef]

63. Zhou, B.; Feng, H.; Pearlstein, A.J. Continuous-flow ultrasonic washing system for fresh produce surface decontamination. Innov. Food Sci. Emerg. Technol. 2012, 16, 427-435. [CrossRef]

64. Mason, T.J. Chemistry with Ultrasound; Elsevier: London, UK, 1990; pp. 1-26.

65. Fan, K.; Zhang, M.; Jiang, F. Ultrasound treatment to modified atmospheric packaged fresh-cut cucumber: Influence on microbial inhibition and storage quality. Ultrason. Sonochem. 2019, 54, 162-170. [CrossRef] [PubMed]

66. Millan-Sango, D.; McElhatton, A.; Valdramidis, V.P. Determination of the efficacy of ultrasound in combination with essential oil of oregano for the decontamination of Escherichia coli on inoculated lettuce leaves. Food Res. Int. 2015, 67, 145-154. [CrossRef]

67. Aday, M.S.; Temizkan, R.; Buyukcan, M.B.; Caner, C. An innovative technique for extending shelf life of strawberry: Ultrasound. LWT Food Sci. Technol. 2013, 52, 93-101. [CrossRef]

68. Wang, W.; Ma, X.; Zou, M.; Jiang, P.; Hu, W.; Li, J.; Zhi, Z.; Chen, J.; Li, S.; Ding, T.; et al. Effects of ultrasound on spoilage microorganisms, quality, and antioxidant capacity of postharvest cherry tomatoes. J. Food Sci. 2015, 80, 2117-2126. [CrossRef]

69. Yilmaz, F.M.; Bilek, S.E. Ultrasound-assisted vacuum impregnation on the fortification of fresh-cut apple with calcium and black carrot phenolics. Ultrason. Sonochem. 2018, 48, 509-516. [CrossRef]

70. Wiktor, A.; Sledz, M.; Nowacka, M.; Rybak, K.; Witrowa-Rajchert, D. The influence of immersion and contact ultrasound treatment on selected properties of the apple tissue. Appl. Acoust. 2016, 103, 136-142. [CrossRef]

71. Gani, A.; Baba, W.N.; Ahmad, M.; Shah, U.; Khan, A.A.; Wani, I.A.; Masoodi, F.A.; Gani, A. Effect of ultrasound treatment on physico-chemical, nutraceutical and microbial quality of strawberry. LWT Food Sci. Technol. 2016, 66, 496-502. [CrossRef]

72. Yu, J.; Engeseth, N.J.; Feng, H. High intensity ultrasound as an abiotic elicitor-effects on antioxidant capacity and overall quality of romaine lettuce. Food Bioproc. Tech. 2016, 9, 262-273. [CrossRef]

73. Huang, T.-S.; Xu, C.; Walker, K.; West, P.; Zhang, S.; Weese, J. Decontamination efficacy of combined chlorine dioxide with ultrasonication on apples and lettuce. J. Food Sci. 2006, 71, 134-139. [CrossRef]

74. Seymour, I.J.; Burfoot, D.; Smith, R.L.; Cox, L.A.; Lockwood, A. Ultrasound decontamination of minimally processed fruits and vegetables. Int. J. Food Sci. Technol. 2002, 37, 547-557. [CrossRef]

75. Forghani, F.; Oh, D.-H. Hurdle enhancement of slightly acidic electrolyzed water antimicrobial efficacy on Chinese cabbage, lettuce, sesame leaf and spinach using ultrasonication and water wash. Food Microbiol. 2013, 36, 40-45. [CrossRef] [PubMed]

76. Bang, H.-J.; Park, S.Y.; Kim, S.E.; Rahman, M.M.F.; Ha, S.-D. Synergistic effects of combined ultrasound and peroxyacetic acid treatments against Cronobacter sakazakii biofilms on fresh cucumber. LWT Food Sci. Technol. 2017, 84, 91-98. [CrossRef]

77. Sagong, H.-G.; Lee, S.-Y.; Chang, P.-S.; Heu, S.; Ryu, S.; Choi, Y.-J.; Kang, D.-H. Combined effect of ultrasound and organic acids to reduce Escherichia coli O157:H7, Salmonella Typhimurium, and Listeria monocytogenes on organic fresh lettuce. Int. J. Food Microbiol. 2011, 145, 287-292. [CrossRef] 
78. Huang, K.; Wrenn, S.; Tikekar, R.; Nitin, N. Efficacy of decontamination and a reduced risk of cross-contamination during ultrasound-assisted washing of fresh produce. J. Food Eng. 2018, 224, 95-104. [CrossRef]

79. Park, S.Y.; Mizan, M.F.R.; Ha, S.-D. Inactivation of Cronobacter sakazakii in head lettuce by using a combination of ultrasound and sodium hypochlorite. Food Control 2016, 60, 582-587. [CrossRef]

80. Afari, G.K.; Hung, Y.-C.; King, H.C.; Hu, A. Reduction of Escherichia coli O157:H7 and Salmonella Typhimurium DT104 on fresh produce using an automated washer with near neutral electrolyzed (NEO) water and ultrasound. Food Control 2016, 63, 246-254. [CrossRef]

81. de Sao Jose, J.F.B.; de Medeiros, H.S.; Bernardes, P.C.; de Andrade, N.J. Removal of Salmonella enterica Enteritidis and Escherichia coli from green peppers and melons by ultrasound and organic acids. Int. J. Food Microbiol. 2014, 190, 9-13. [CrossRef] [PubMed]

82. Yang, Z.; Cao, S.; Cai, Y.; Zheng, Y. Combination of salicylic acid and ultrasound to control postharvest blue mold caused by Penicillium expansum in peach fruit. Innov. Food Sci. Emerg. Technol. 2011, 12, 310-314. [CrossRef]

83. Ding, T.; Ge, Z.; Shi, J.; Xu, Y.-T.; Jones, C.L.; Liu, D.-H. Impact of slightly acidic electrolyzed water (SAEW) and ultrasound on microbial loads and quality of fresh fruits. LWT Food Sci. Technol. 2015, 60, 1195-1199. [CrossRef]

84. de Sao Jose, J.F.B.; Vanetti, M.C.D. Effect of ultrasound and commercial sanitizers in removing natural contaminants and Salmonella enterica Typhimurium on cherry tomatoes. Food Control 2012, 24, 95-99. [CrossRef]

85. Wang, J.; Fan, L. Effect of ultrasound treatment on microbial inhibition and quality maintenance of green asparagus during cold storage. Ultrason. Sonochem. 2019, 58, 104631. [CrossRef] [PubMed]

86. Mansur, A.R.; Oh, D.-H. Combined effect of thermosonication and slightly acidic electrolyzed water to reduce foodborne pathogens and spoilage microorganisms on fresh-cut kale. J. Food Sci. 2015, 80, 1277-1284. [CrossRef] [PubMed]

87. Mansur, A.R.; Oh, D.-H. Combined effects of thermosonication and slightly acidic electrolyzed water on the microbial quality and shelf life extension of fresh-cut kale during refrigeration storage. Food Microbiol. 2015, 51, 154-162. [CrossRef] [PubMed]

88. Vivek, K.; Subbarao, K.V.; Srivastava, B. Optimization of postharvest ultrasonic treatment of kiwifruit using RSM. Ultrason. Sonochem. 2016, 32, 328-335. [CrossRef]

89. Meng, X.; Zhang, M.; Adhikari, B. The effects of ultrasound treatment and nano-zinc oxide coating on the physiological activities of fresh-cut kiwifruit. Food Bioproc. Tech. 2014, 7, 126-132. [CrossRef]

90. Cao, S.; Hu, Z.; Pang, B. Optimization of postharvest ultrasonic treatment of strawberry fruit. Postharvest Biol. Technol. 2010, 55, 150-153. [CrossRef]

91. Pinheiro, J.; Alegria, C.; Abreu, M.; Goncalves, E.M.; Silva, C.L.M. Influence of postharvest ultrasounds treatments on tomato (Solanum lycopersicum, cv. Zinac) quality and microbial load during storage. Ultrason. Sonochem. 2015, 27, 552-559. [CrossRef]

92. Esua, O.J.; Chin, N.L.; Yusof, Y.A.; Sukor, R. Combination of ultrasound and ultraviolet-C irradiation on kinetics of color, firmness, weight loss, and total phenolic content changes in tomatoes during storage. J. Food Process. Preserv. 2019, 43, 14161. [CrossRef]

93. Feng, H.; Yang, W.; Hielscher, T. Power ultrasound. Food Sci. Technol. Int. 2008, 14, 433-436. [CrossRef]

94. Yan, R.; Yun, J.; Gurtler, J.; Fan, X. Radiochromic film dosimetry for UV-C treatments of apple fruit. Postharvest Biol. Technol. 2017, 127, 14-20. [CrossRef]

95. Fan, X.; Thayer, D.W. Quality of irradiated alfalfa sprouts. J. Food Protect. 2001, 64, 1574-1578. [CrossRef]

Publisher's Note: MDPI stays neutral with regard to jurisdictional claims in published maps and institutional affiliations. 